\title{
U-Series disequilibria in subduction zone lavas: inherited from subducted slabs or produced by mantle in-growth melting?
}

\author{
Fang Huang*, Juan Xu, Julin Zhang
}

CAS Key Laboratory of Crust-Mantle Materials and Environments, School of Earth and Space Sciences, University of Science and Technology of China, Hefei 230026, China.

6670 words, 12 figures, 2 SOM tables.

* Correspondences and requests for materials should be addressed to F. Huang (fhuang@ustc.edu.cn). 


\section{Abstract}

U-series disequilibria of subduction zone lavas have been used to provide temporal constraints on flux transfer in convergent margins. There are debates on whether the disequilibria are inherited from the source modified by slab materials (fluids or sediments) or produced by in-growth melting of the mantle. After filtering out the effect of crustal modification on U-series data, $\left({ }^{226} \mathrm{Ra}\right) /\left({ }^{230} \mathrm{Th}\right)$ is not positively correlated with $\mathrm{Sr} / \mathrm{Th}$ and $\mathrm{Ba} / \mathrm{Th}$ in arc basalts with $\mathrm{SiO}_{2}<52 \mathrm{wt} \%$. This invalidates the key evidence for addition of slab-fluids to the mantle producing ${ }^{226} \mathrm{Ra}$ excess in subduction zone lavas. Sediment melts with a zircon-free residue may have ${ }^{231} \mathrm{~Pa}$ excess, but it is not consistent with the overwhelming $\mathrm{Zr}$-Hf depletions in subduction zone lavas, which instead require a zircon-saturated residue during sediment melting.

With appropriate parameters applied, in-growth melting in the mantle followed by modification in the crust can provide a self-consistent explanation of the U-series disequilibria and the relationships with other geochemical signatures in most subduction zone lavas except the few Tonga-Kermadec lavas with slight ${ }^{231} \mathrm{~Pa}$ deficit. On the basis of melting experiments of hydrous peridotites, we further propose that most mantle-derived melts and thus U-series disequilibria should be mainly produced by melting in the hot zone of the mantle wedge, as controlled by thermal structure of the convergent margins. In order to produce enough short-lived nuclides, the timescales of mass transfer and magmatism in the subduction zone should at least range from a few to a few hundred millennia. Future studies on more lavas, numerical modeling, and partition coefficients of U-series nuclides will help for better 
application of U-series disequilibria into subduction zone magmatism.

Keyword: U-series disequilibria, subduction zone lavas, convergent margin, in-growth melting

\section{Introduction}

Subduction zones are the vital site for crustal recycling, mantle melting, juvenile crust growth, and ore-deposit forming (Rudnick, 1995; Sillitoe, 2010; Jagoutz and Kelemen, 2015). Addition of volatile fluxes derived from the subducted slabs to the wedge lowers the solidus of the mantle peridotites and triggers partial melting of the mantle (Gill, 1981; Schmidt and Poli, 1998; Grove et al., 2006). One of the key questions of subduction zones is the timescale and process of volatile transfer from the slab to the wedge during subduction and consequential magmatism.

U-series nuclides can be fractionated during dehydration and partial melting (Brenan et al., 1995; LaTourrette et al., 1995; Keppler, 1996; Blundy and Wood, 2003), resulting in U-series disequilibria in igneous rocks. Because the parent-daughter disequilibria decay back to secular equilibrium after five half-lives $\left(\tau_{1 / 2}\right)$ of the short-lived nuclides since the fractionation, the disequilibria have provided a unique and powerful tool to constrain the timescales of fluid transfer and magmatism in the convergent margins and other tectonic settings (e.g., Bourdon and Sims, 2003; Lundstrom, 2003; Turner et al., 2003a; Dosseto et al., 2010). Figure 1 summarizes the subduction zone volcanoes where lavas have been studied for U-series disequilibria. In this review, the volcanoes are classified as island arcs built on oceanic crust and continental margin volcanoes (CMV) on continental crust. 
There is an increasing consensus that U-series disequilibria are observed in young subduction zone lavas. Hereafter, (daughter)/(parent) is used to denote the radioactive ratio of the daughter nuclide over the parent nuclide. Most young lavas have $\left({ }^{231} \mathrm{~Pa}\right) /\left({ }^{235} \mathrm{U}\right)$ and $\left({ }^{226} \mathrm{Ra}\right) /\left({ }^{230} \mathrm{Th}\right)>1$; the majority of young lavas have $\left({ }^{238} \mathrm{U}\right) /\left({ }^{230} \mathrm{Th}\right)>$ 1, while a substantial amount of samples have ${ }^{230} \mathrm{Th}$ excess; and a significant number of historical lavas are in ${ }^{238} \mathrm{U}_{-}{ }^{230}$ Th equilibrium, which is clearly not a result of the ageing effect (Reubi et al., 2014). However, the origin of the disequilibria is still contentious, leading to contrasting views of the temporal implications for the magmatism in convergent margins. Although it has been recognized that crustal melting can produce ${ }^{230}$ Th-enriched lavas, such as in the case of Cascadia (Wende et al., 2015; Ankney et al., 2016), the main debates focus on whether U-series disequilibria observed in the subduction zone lavas are inherited from the mantle source metasomatized by slab-derived fluxes, or whether they are produced by in-growth melting in the mantle, the latter being a physically similar process which has been used to explain the U-series disequilibria in mid-ocean ridge basalts (MORB) and ocean island basalts (OIB) (e.g., McKenzie, 1985; Spiegelman and Elliott, 1993; Spiegelman, 1996; McKenzie, 2000).

It has been accepted that $\mathrm{Ra}$ and $\mathrm{U}$ are more fluid-mobile than $\mathrm{Th}$ and $\mathrm{Pa}$ during the slab dehydration (Keppler and Wyllie, 1990; Keppler, 1996). Therefore, the ${ }^{226} \mathrm{Ra}$ and ${ }^{238} \mathrm{U}$ excesses over ${ }^{230} \mathrm{Th}$ in subduction zone lavas have been widely interpreted to reflect the features of the mantle source metasomatized by slab-fluids enriched in Ra and U (e.g., Elliott et al., 1997; Regelous et al., 1997; Heath et al., 1998; Chabaux et 
al., 1999; Turner et al., 2000; Zellmer et al., 2000; Turner et al., 2001; Sigmarsson et al., 2002; Dosseto et al., 2003; Turner et al., 2003a; Yokoyama et al., 2003; DuFrane et al., 2009). More recently, based on experimental studies on partitioning of U-series nuclides between accessory minerals and fluids, it was proposed that accessory minerals (such as zircon and allanite) could play a key role in producing U-series disequilibria in hydrous fluid or sediment melt. If such signatures are introduced to the mantle wedge and further inherited in subduction zone lavas (Avanzinelli et al., 2012), the timescales of fluid transfer and magmatism should be within five $\tau_{1 / 2}$ of the short-lived nuclides (e.g., ${ }^{230} \mathrm{Th}$ with a $\tau_{1 / 2}$ of 75600 years, ${ }^{231} \mathrm{~Pa}$ with a $\tau_{1 / 2}$ of 32800 years, and ${ }^{226} \mathrm{Ra}$ with a $\tau_{1 / 2}$ of 1600 years). For instance, ${ }^{226} \mathrm{Ra}$ excess in subduction zone lavas implies that the timescale should be $<8000$ years; in some extreme cases (e.g., in Tonga), it could be even within a few hundreds of years (Turner et al., 2000; Turner et al., 2001).

Because Pa is generally regarded as immobile in hydrous fluids (Keppler, 1996), U-rich fluid addition to the wedge can create ${ }^{231} \mathrm{~Pa}$ deficit in the mantle source. This is not consistent with the ${ }^{231} \mathrm{~Pa}$ excess ubiquitously observed in subduction zone lavas (Pickett and Murrell, 1997; Dosseto et al., 2003; Turner et al., 2006). Therefore, the in-growth melting model was adopted to explain the ${ }^{231} \mathrm{~Pa}$ (and ${ }^{230} \mathrm{Th}$ ) excesses in lavas (Thomas et al., 2002; Huang et al., 2011; Reubi et al., 2011; Reubi et al., 2014). Such a model requires that the timescale for mantle melting should be at least comparable to the $\tau_{1 / 2}$ of ${ }^{231} \mathrm{~Pa}$ and ${ }^{230} \mathrm{Th}$ so that enough ${ }^{231} \mathrm{~Pa}$ and ${ }^{230} \mathrm{Th}$ can be produced to overprint the original ${ }^{231} \mathrm{~Pa}$ and ${ }^{230} \mathrm{Th}$ deficits in the metasomatized 
mantle. That is, the initial status of the mantle source may not be related to the final disequilibria in the lavas at all (e.g., Huang et al., 2008; Reubi et al., 2014).

The contrasting interpretations for the U-series disequilibria of subduction zone lavas reflect the physical and chemical complexity of flux transfer and magmatism in the convergent margin. This is further complicated by a number of processes including dehydration and melting in the slabs, convection and melting in the mantle, and magma differentiation in the crust (Schmidt and Poli, 1998; Turner et al., 2003a; Cagnioncle et al., 2007; Avanzinelli et al., 2008; Huang et al., 2011; Reubi et al., 2011; Mitchell and Asmerom, 2011; Reubi et al., 2014). Here we compile U-series data published in the last two decades and provide a critical review on how U-series disequilibria are generated in subduction zone lavas. After carefully examining the key factors which can modify the U-series disequilibria, we propose a self-consistent model showing that in-growth mantle melting could be the best explanation for these observations.

\section{Observations of U-series disequilibria}

\subsection{Data filtering}

Because U-series disequilibria are sensitive to decay since magma eruption, it is critical to know the eruption age in order to calculate the initial disequilibria of the lavas. U-series data for whole rocks published in the literature are summarized in the supplementary online material (SOM Table 1) and the data sources are listed in SOM Table 2. The data without known eruption ages or older than 100 kyrs are excluded because of the large uncertainty of calculation of the initial disequilibrium ratios. 
Some samples do not have accurate eruption ages, but stratigraphic evidences or historical records show that they are young relative to the $\tau_{1 / 2}$ of ${ }^{230} \mathrm{Th}$ (Walker et al., 2007; Price et al., 2010). Therefore, the decay after magma eruption is negligible and their ${ }^{238} \mathrm{U}_{-}^{230} \mathrm{Th}$ data are still used in this review. With these criteria, we obtained 1142 age-corrected data for $\left({ }^{230} \mathrm{Th}\right) /\left({ }^{238} \mathrm{U}\right), 173$ for $\left({ }^{231} \mathrm{~Pa}\right) /\left({ }^{235} \mathrm{U}\right)$, and 423 for $\left({ }^{226} \mathrm{Ra}\right) /\left({ }^{230} \mathrm{Th}\right)$ for the subduction zone lavas (SOM Table 1). Combined with other geochemical data, this dataset allows us to better understand how U-series disequilibria are generated in the mantle (or slab-wedge boundary) and sequentially modified in the crust.

\subsection{Global observations}

Figure 2 is the equiline diagram for $\left({ }^{238} \mathrm{U}\right) /\left({ }^{232} \mathrm{Th}\right)-\left({ }^{230} \mathrm{Th}\right) /\left({ }^{232} \mathrm{Th}\right)$ of the island arc and CMV lavas. It is clearly shown that more island arc lavas have ${ }^{238} \mathrm{U}$ excess over ${ }^{230}$ Th than the CMV lavas. Notably, both ${ }^{238} \mathrm{U}$ excess and deficit can be observed in the same arcs such as the Marianas (Fig. 2a) and Nicaragua (Fig. 2b), indicating the complicated behavior of U-series nuclides during volatile transfer and magmatism. Marianas lavas have a positive trend between $\left({ }^{238} \mathrm{U}\right) /\left({ }^{232} \mathrm{Th}\right)$ and $\left({ }^{230} \mathrm{Th}\right) /\left({ }^{232} \mathrm{Th}\right)$ (Elliott et al., 1997), but because the lavas were sampled from the arc with a length of thousands of kilometers, unlikely to fit the criteria for an ideal isochron, such a trend cannot be simply treated as an isochron like the case used for mineral dating (Condomines et al., 2003).

$\left({ }^{231} \mathrm{~Pa}\right) /\left({ }^{235} \mathrm{U}\right)$ of the CMV and island arc lavas are plotted against $\left({ }^{226} \mathrm{Ra}\right) /\left({ }^{230} \mathrm{Th}\right)$, $\left({ }^{230} \mathrm{Th}\right) /\left({ }^{238} \mathrm{U}\right)$, and $\left({ }^{226} \mathrm{Ra}\right) /\left({ }^{238} \mathrm{U}\right)$ in Fig. 3. Despite the contrasting fluid mobility between $\mathrm{Pa}$ and $\mathrm{Ra}$, most lavas simultaneously have ${ }^{231} \mathrm{~Pa}$ and ${ }^{226} \mathrm{Ra}$ excesses, which 
cannot be explained by a recent addition of $\mathrm{Ra}-\mathrm{U}$ rich fluid to the mantle wedge (Fig. 3A and 3B). The CMV lavas generally have higher $\left({ }^{230} \mathrm{Th}\right) /\left({ }^{238} \mathrm{U}\right)$ and smaller ranges of $\left({ }^{226} \mathrm{Ra}\right) /\left({ }^{230} \mathrm{Th}\right)$ and $\left({ }^{231} \mathrm{~Pa}\right) /\left({ }^{235} \mathrm{U}\right)$ than the island arc lavas. Another important observation is that most subduction zone lavas have $\left({ }^{226} \mathrm{Ra}\right) /\left({ }^{238} \mathrm{U}\right)$ greater than unity, likely suggesting that $\mathrm{Ra}$ is more fluid-mobile than $\mathrm{U}$ during dehydration or more incompatible during partial melting.

The distribution frequencies of $\left({ }^{230} \mathrm{Th}\right) /\left({ }^{238} \mathrm{U}\right),\left({ }^{231} \mathrm{~Pa}\right) /\left({ }^{235} \mathrm{U}\right)$, and $\left({ }^{226} \mathrm{Ra}\right) /\left({ }^{230} \mathrm{Th}\right)$ quantitatively reveal the differences of U-series disequilibria between the island arc and the CMV lavas (Fig. 4). The U-series daughter is regarded to be in disequilibrium with the parent if their radioactivity ratio deviates from unity beyond the typical analytical errors, e.g., $~ 1.5 \%(2 \mathrm{SD})$ for $\left({ }^{230} \mathrm{Th}\right) /\left({ }^{238} \mathrm{U}\right), 3 \%$ for $\left({ }^{226} \mathrm{Ra}\right) /\left({ }^{230} \mathrm{Th}\right)$, and $5 \%$ for $\left({ }^{231} \mathrm{~Pa}\right) /\left({ }^{235} \mathrm{U}\right)$ (Dosseto et al., 2003; George et al., 2003; Turner et al., 2006; Sims et al., 2008; Koornneef et al., 2010; Reubi et al., 2011). With these criteria, $8.2 \%$ of island arc lavas and $15 \%$ of the CMV lavas are within ${ }^{238} \mathrm{U}^{2}{ }^{230} \mathrm{Th}$ equilibrium, but it does not result from ageing after eruption given the young eruption ages (SOM Table 1). $76.4 \%$ of island arc lavas and $47.4 \%$ of the CMV lavas have ${ }^{238} \mathrm{U}$ excess over ${ }^{230}$ Th. $15.4 \%$ of island arc lavas and $37.5 \%$ of the CMV lavas have ${ }^{230}$ Th excess over ${ }^{238} \mathrm{U}$ (Fig. 4). These observations were also recently summarized in Reubi et al. (2014).

Except for the few samples with ${ }^{231} \mathrm{~Pa}$ deficits reported in early studies on the Tonga and Kermadec arcs (Pickett and Murrell, 1997; Bourdon et al., 1999), ${ }^{231} \mathrm{~Pa}$ excess over ${ }^{235} \mathrm{U}$ is ubiquitously observed in subduction zone lavas with $\left({ }^{231} \mathrm{~Pa}\right) /\left({ }^{235} \mathrm{U}\right)$ 
ranging up to 2.65 (Pickett and Murrell, 1997; Thomas et al., 2002; Dosseto et al., 2003; Turner et al., 2006; Huang et al., 2011). The highest ${ }^{231} \mathrm{~Pa}$ excess is observed in the South Lesser Antilles arc, which also has the slowest convergent rate in global subduction zones (Gill, 1981; Turner et al., 2006; Huang and Lundstrom, 2007). Compared to other high-field-strength elements (HFSE, such as $\mathrm{Nb}$ and $\mathrm{Ta}$ ), $\mathrm{Pa}$ is enriched in subduction zone lavas in the primitive mantle normalized patterns, similar to the fluid-mobile large-ion-lithophile elements (LILE, such as Ba and Rb) (Huang et al., 2011).

The $\left({ }^{226} \mathrm{Ra}\right) /\left({ }^{230} \mathrm{Th}\right)$ of island arc lavas range from 0.878 to 6.131 , with the highest ${ }^{226} \mathrm{Ra}$ excess reported in the Tonga arc with the fastest convergent rate (Turner et al., 1997; Turner et al., 2000). Except for two lavas from the Vesuvius volcano (erupted in 1944 AD) with extremely high $\left({ }^{226} \mathrm{Ra}\right) /\left({ }^{230} \mathrm{Th}\right)$ of 8.194 and 8.667 (Black et al., 1998), $\left({ }^{226} \mathrm{Ra}\right) /\left({ }^{230} \mathrm{Th}\right)$ of the CMV lavas range from 0.96 to 3.529 (Fig. 4C) (Chabaux et al., 1999; Turner et al., 2000; Turner et al., 2001; Sigmarsson et al., 2002; Thomas et al., 2002; Dosseto et al., 2003; Touboul et al., 2007; Turner et al., 2007; Huang et al., 2011). These observations indicate that the timescale since the development of disequilibria is within $8 \mathrm{ka}$, too short to significantly modify $\left({ }^{231} \mathrm{~Pa}\right) /\left({ }^{235} \mathrm{U}\right)$ and $\left({ }^{230} \mathrm{Th}\right) /\left({ }^{238} \mathrm{U}\right)$ data by the ageing effect.

\section{How are U-series disequilibria generated in subduction zone lavas?}

Because U-series nuclides can be fractionated by slab dehydration, sediment melting, diffusive transport, and in-growth melting, numerous models have been developed to account for the U-series disequilibria in subduction zone lavas 
(Feineman and DePaolo, 2003; Turner et al., 2003a; Huang et al., 2011; Avanzinelli et al., 2012). An ideal model should be geologically and physically reasonable, self-consistent for all parent-daughter pairs, in agreement with the thermal structure of the mantle wedge, and in line with other geochemical and petrological signatures. In the following, we critically review the pros and cons of the four models widely adopted in the literature.

\subsection{Slab-fluid addition}

\subsection{1 ${ }^{231} \mathrm{~Pa}^{235} \mathrm{U}$ system}

Protactinium is generally considered as more immobile than $U$ during dehydration of the subducted slab (Keppler, 1996; Turner et al., 2003a). Therefore, a recent addition of slab-derived fluids to the mantle wedge can produce $\mathbf{a}^{231} \mathrm{~Pa}$ deficit relative to ${ }^{235} \mathrm{U}$ in subduction zone lavas, such as the early observation of ${ }^{231} \mathrm{~Pa}$ deficit in the few samples from the Tonga-Kermadec lavas (Pickett and Murrell, 1997; Bourdon et al., 1999). However, such a signal has never been observed again since these pioneering studies. Instead, later studies exclusively reported ${ }^{231} \mathrm{~Pa}$ excess in subduction zone lavas (Thomas et al., 2002; Dosseto et al., 2003; Turner et al., 2006; Huang and Lundstrom, 2007; Huang et al., 2011; Reubi et al., 2011), suggesting that the original ${ }^{231} \mathrm{~Pa}$ deficit in the mantle wedge (if any) should have been completely overprinted by the later melting process. Because ${ }^{231} \mathrm{~Pa}$ deficit in lavas are so rare relative to the overwhelming ${ }^{231} \mathrm{~Pa}$ excess, re-visiting young lavas from the Tonga-Kermadec arc would be desirable for better understanding the effects of slab dehydration and mantle melting on U-series disequilibria. 


\subsection{2 ${ }^{238} \mathrm{U}_{-}^{230} \mathrm{Th}^{2}{ }^{226} \mathrm{Ra}$ system}

The positive correlations between "fluid indices" (such as $\mathrm{Sr} / \mathrm{Th}$ and $\mathrm{Ba} / \mathrm{Th}$ ) and $\left({ }^{226} \mathrm{Ra}\right) /\left({ }^{230} \mathrm{Th}\right)$ have been regarded as a strong evidence for the addition of slab-derived fluids enriched with $\mathrm{Ra}, \mathrm{Sr}$, and $\mathrm{Ba}$ to generate $\mathrm{U}$-series disequilibria in the mantle wedge and subduction zone lavas (Turner et al., 2003a; Dosseto et al., 2010). Indeed, the fluid addition model predicts that $\left({ }^{226} \mathrm{Ra}\right) /\left({ }^{230} \mathrm{Th}\right)$ of a primitive magma should be coupled with U/Th, Sr/Th, and Ba/Th (Turner et al., 2001). However, because most lavas erupted at the convergent margin have experienced different extent of magma differentiation, Huang et al. (2011) proposed that the large variations of $\mathrm{Sr} / \mathrm{Th}$ and $\mathrm{Ba} / \mathrm{Th}$ may be alternatively explained by magma differentiation (see more discussion in section 5.1). U-series data can also be modified in the crust by mixing with recharging melt or crustal materials, ageing, and crystallization (MAC) (Huang et al., 2008). Therefore, in order to address the role of fluid addition, it is critical to filter out the effect of crustal modification on "fluid indices".

To distinguish the signatures inherited from the metasomatized source from those developed in the MAC processes, the CMV and island arc lavas are grouped based on $\mathrm{SiO}_{2}$ contents in Fig. 5 and Fig. 6, respectively. Presumably, the signatures inherited from the mantle source should be less affected in lavas with $\mathrm{SiO}_{2}<52$ wt\% (i.e., basalts) than in the more evolved lavas with higher $\mathrm{SiO}_{2}$ content. However, as depicted in Fig. 5, the basalts from Kamchatka, Alaska, and South Volcanic Zone (SVZ) from Andes do not show positive correlation among $\mathrm{Ba} / \mathrm{Th}, \mathrm{Sr} / \mathrm{Th}$, 
$\left({ }^{238} \mathrm{U}\right) /\left({ }^{230} \mathrm{Th}\right)$, and $\left({ }^{226} \mathrm{Ra}\right) /\left({ }^{230} \mathrm{Th}\right)$. Instead, $\left({ }^{226} \mathrm{Ra}\right) /\left({ }^{230} \mathrm{Th}\right)$ of Kamchatka (open red star) and Alaska lavas (open blue diamond) with $\mathrm{SiO}_{2}>52 \mathrm{wt} \%$ are positively correlated with $\mathrm{Sr} / \mathrm{Th}$ and $\mathrm{Ba} / \mathrm{Th}$ (Fig. 5D and 5E). The positive correlation between $\left({ }^{238} \mathrm{U}\right) /\left({ }^{230} \mathrm{Th}\right)$ and $\left({ }^{226} \mathrm{Ra}\right) /\left({ }^{230} \mathrm{Th}\right)$ is only observed in the evolved lavas in the SVZ, not in the CMV basalts (Fig. 5).

The lack of positive correlations among fluid indices is also obvious in island arc basalts (Fig. 6). The Tonga-Kermadec and Marianas basalts even show a roughly negative correlation between $\mathrm{Ba} / \mathrm{Th}$ and $\left({ }^{226} \mathrm{Ra}\right) /\left({ }^{230} \mathrm{Th}\right)$, in contrast to the previous notion without classifying the evolved lavas from the primitive ones (Turner et al., 2001). Although $\left({ }^{226} \mathrm{Ra}\right) /\left({ }^{230} \mathrm{Th}\right)$ in Vanuatu basalts is weakly correlated with $\mathrm{Sr} / \mathrm{Th}$, but it does not change with $\mathrm{Ba} / \mathrm{Th}$, a parameter less likely modified by fractional crystallization in mafic lavas. The $\left({ }^{226} \mathrm{Ra}\right) /\left({ }^{230} \mathrm{Th}\right)$ of Stromboli and Lesser Antilles basalts are not correlated with $\mathrm{Sr} / \mathrm{Th}, \mathrm{Ba} / \mathrm{Th}$, or $\left({ }^{238} \mathrm{U}\right) /\left({ }^{230} \mathrm{Th}\right)$ either. Sunda basalts show a scattered distribution in Fig. 6. Although one Sunda basalt has high $\mathrm{Ba} / \mathrm{Th}$, Sr/Th, and $\left({ }^{226} \mathrm{Ra}\right) /\left({ }^{230} \mathrm{Th}\right)$, it also has ${ }^{230} \mathrm{Th}$ excess over ${ }^{238} \mathrm{U}$ (Turner et al., 2003b), not consistent with the simple explanation of fluid addition.

Similar to the CMVs, the positive correlations among the "fluid indices" are tentatively shown in island arc lavas with $\mathrm{SiO}_{2}>52 \mathrm{wt} \%$, such as the evolved Tonga-Kermadec lavas (Fig. 6). Indeed, these features have been better observed in lavas erupted from a single volcano, such as the case of Kick'em Jenny submarine volcano from the South Lesser Antilles (Huang et al., 2011) and Volcán Llaima from Chile (Reubi et al., 2011). Therefore, if the effect of magma differentiation is 
considered, there is no convincing evidence (except for the ${ }^{231} \mathrm{~Pa}$ deficit in the few Tonga-Kermadec lavas) to support that the subduction zone lavas inherit the disequilibria from the slab-derived fluids.

\subsection{Sediment controlling}

Slab sediments dominate the budgets of recycled incompatible elements into the mantle (Turner et al., 1996; Plank and Langmuir, 1998). Experimental studies show that accessory minerals (such as allanite, monazite, and zircon) can be stable in the subducted slabs, and they can fractionate U-series nuclides more than clinopyroxene and garnet during partial melting and dehydration (Hermann, 2002; Rubatto and Hermann, 2007; Hermann and Rubatto, 2009). Therefore, Avanzinelli et al. (2012) proposed an alternative explanation for U-series disequilibria in the subduction zone lavas, relating to accessory minerals with different stability at variable thermal and chemical conditions. Specifically, as Th is more compatible in monazite and allanite (Hermann, 2002) and $\mathrm{Pa}$ is more compatible in zircon than $\mathrm{U}$ (Schmitt, 2007), monazite and zircon-free sediment melts could have ${ }^{231} \mathrm{~Pa}$ and ${ }^{230} \mathrm{Th}$ excesses. Furthermore, aqueous fluids from the slabs could have ${ }^{231} \mathrm{~Pa}$ excess and ${ }^{238} \mathrm{U}$ excess if allanite is saturated and zircon is free in the residual phases during dehydration. If both allanite and zircon are saturated in the residual assemblage, the slab-released fluids could have low $\left({ }^{230} \mathrm{Th}\right) /\left({ }^{238} \mathrm{U}\right)$ and $\left({ }^{231} \mathrm{~Pa}\right) /\left({ }^{235} \mathrm{U}\right)$ (Avanzinelli et al., 2012).

Although processes involving accessory minerals may produce certain disequilibrium signatures in slab-derived melts or hydrous fluids, some essential hypotheses still need rigorous testing. First of all, because zircon is the main host 
mineral for $\mathrm{Zr}$ and $\mathrm{Hf}$ in slab sediments (Plank and Langmuir, 1998), the overwhelming depletions of $\mathrm{Zr}$ and $\mathrm{Hf}$ in subduction zone lavas relative to the LILE strongly support the existence of residual zircon during dehydration and melting in the slabs (Gill, 1981; Elliott et al., 1997). Furthermore, Avanzinelli et al. (2012) argue that zircon-free fluids can explain the high $\left({ }^{231} \mathrm{~Pa}\right) /\left({ }^{235} \mathrm{U}\right)$ in the Lesser Antilles (including Kick'em Jenny) lavas, while zircon-saturated fluids may account for the low $\left({ }^{231} \mathrm{~Pa}\right) /\left({ }^{235} \mathrm{U}\right)$ in Tonga-Kermadec lavas. However, such explanations are not consistent with the lower $\mathrm{Zr} / \mathrm{Pa}$ in Lesser Antilles lavas than in Tonga-Kermadec because the zircon-free fluids should have high $\mathrm{Zr} / \mathrm{Pa}$ (Fig. 7). Therefore, adding slab-components controlled by accessory minerals to the wedge may not be a satisfactory explanation for the U-series disequilibria and HFSE data in subduction zone lavas.

\subsection{Diffusion}

Because Ra diffuses much faster than $\mathrm{Th}$ in clinopyroxene and $\mathrm{Ra}$ and $\mathrm{Ba}$ are strongly enriched in amphibole and phlogopite in hydrous mantle, Feineman and DePaolo (2003) proposed that a steady state, where amphibole and phlogopite have significant ${ }^{226} \mathrm{Ra}$ excess over ${ }^{230} \mathrm{Th}$ relative to the neighboring clinopyroxene, could be established in the mantle wedge. Therefore, a preferential contribution of amphibole and phlogopite to the mantle-derived melt could produce the ${ }^{226} \mathrm{Ra}$ excess observed in subduction zone lavas (Feineman and DePaolo, 2003). This proposal implies that ${ }^{226} \mathrm{Ra}$ excess should be associated with a strong potassic composition in subduction zone lavas because amphibole and phlogopite are also enriched in $\mathrm{K}$. This prediction 
is not consistent with the high ${ }^{226} \mathrm{Ra}$ excess and low $\mathrm{K}$ content in the Tonga lavas (Dosseto et al., 2003; George et al., 2004). Therefore, as suggested in George et al. (2004), although the diffusion of Ra between the coexisting minerals may account for the ${ }^{226} \mathrm{Ra}$ excess in some cases, such as in potassic lavas, it should not be a general mechanism for the U-series disequilibria observed in subduction zone lavas.

\subsection{In-growth melting}

A number of quantitative in-growth melting models have been developed to simulate U-series disequilibria in the MORB and OIB (Newman et al., 1984; McKenzie, 1985; Spiegelman and Elliott, 1993; Spiegelman, 1996; Bourdon and Sims, 2003; Lundstrom, 2003). Basically, during partial melting of the upper mantle, U-series nuclides with different effective velocities have various residence times, long enough to in-grow short-lived nuclides. The daughter is further fractionated from the parent during melting in a peridotite matrix with low porosity. Although in-growth melting was used to explain ${ }^{231} \mathrm{~Pa}$ and ${ }^{230} \mathrm{Th}$ excesses in subduction zone lavas (Thomas et al., 2002; Turner et al., 2006; Huang and Lundstrom, 2007), it was not originally considered important for the ${ }^{226} \mathrm{Ra}$ excess because it cannot produce the correlations of ${ }^{226} \mathrm{Ra}$ excess with $\mathrm{Sr} / \mathrm{Th}$ and $\mathrm{Ba} / \mathrm{Th}$ (Dosseto et al., 2003; Turner et al., 2003a). However, as discussed above, because there is no correlation among $\mathrm{Ra} / \mathrm{Th}$, $\mathrm{Sr} / \mathrm{Th}$, and $\mathrm{Ba} / \mathrm{Th}$ in arc basalts, all evidences against in-growth melting is invalidated. Thus, in-growth melting should be re-considered to explain U-series disequilibria in subduction zone lavas.

One of the attractive aspects of the in-growth melting model is that it can provide 
a self-consistent and straightforward explanation for the disequilibria of parent-daughter pairs with dramatically different $\tau_{1 / 2}$ and geochemical behaviors. Sophisticated processes have been proposed to account for the coexistence of ${ }^{226} \mathrm{Ra}$ and ${ }^{238} \mathrm{U}$ excesses with ${ }^{231} \mathrm{~Pa}$ excess (Bourdon et al., 2003; Turner et al., 2003a). In the scenario of in-growth melting, the duration of time required should be at least comparable to the $\tau_{1 / 2}$ of ${ }^{231} \mathrm{~Pa}$ to produce enough ${ }^{231} \mathrm{~Pa}$ and it is much longer than the $\tau_{1 / 2}$ of ${ }^{226} \mathrm{Ra}$ so that the initial ${ }^{226} \mathrm{Ra}$ excess produced by slab-derived fluids may decay away. But it does not matter for the observations in subduction zone lavas, because in-growth melting can produce significant ${ }^{226} \mathrm{Ra}$ (and ${ }^{238} \mathrm{U}$ ) excess in the melt (Huang and Lundstrom, 2007; Huang et al., 2011; Reubi et al., 2014). Therefore, in-growth melting may be the best interpretation for the observed U-series disequilibria.

\section{Review of in-growth melting models}

Flux melting (FM), dynamic melting (DM), and equilibrium transport melting (ETM) have been used to explain U-series disequilibria of subduction zone lavas (Thomas et al., 2002; Turner et al., 2006; Huang and Lundstrom, 2007). The essence of the in-growth models is similar in terms of fractionating U-series nuclides by melting in low porosity matrix. Here we briefly summarize the principles of the three in-growth melting models.

\subsection{Flux melting}

With the current geothermal gradient, the mantle wedge cannot be partially melted unless slab-derived volatiles are added to lower the solidus of peridotites. The FM model assumes that instantaneously adding fluid to hot mantle results in 
immediate melting (Fig. 8A). Therefore, the different residence times of U-series nuclides are produced at the beginning of the fluid addition and melting process (Thomas et al., 2002; Bourdon et al., 2003). The time-scale of melting should be long enough to in-grow ${ }^{231} \mathrm{~Pa}$ and ${ }^{230} \mathrm{Th}$ to overprint the possible initial ${ }^{231} \mathrm{~Pa}$ and ${ }^{230} \mathrm{Th}$ deficit in the slab-derived melts (Thomas et al., 2002). Because U-series disequilibria of lavas are produced in the deep melting zone right above the slab-wedge boundary, the FM model implies fast melt converging and transport upward from the upper mantle to the crust.

\subsection{Dynamic melting}

The DM model assumes that once the melt fraction reaches a given threshold, the melt is instantaneously extracted and transported out of the melting zone without further interaction with the solid matrix (McKenzie, 1985; Bourdon and Sims, 2003). The DM model is similar to the FM model in the ways of creating different residence times of U-series nuclides. DM could occur above the slab-wedge boundary as soon as hydrous fluids lower the solidus of peridotites, followed by melt focusing and fast extraction to the shallow magma chamber (Turner et al., 2003a). Alternatively, it could also occur due to decompressional melting in the upwelling hot zone or in the limb of the wedge following the mantle flow (Fig. 8B) (Elkins-Tanton et al., 2001).

\subsection{Equilibrium transport melting}

Based on the physics of buoyancy-driven melt transport, the ETM model assumes that the melt is in constant equilibrium with mineral grains when it percolates through the solid matrix (Spiegelman and Elliott, 1993; Spiegelman, 1996). The difference of 
in residence time of U-series nuclides is produced by the chromatographic effect in the melting zone, which does not require a specific focusing and fast transport of melt from the mantle to the arc volcanoes. Furthermore, a longer melting column could produce larger U-series disequilibria as demonstrated in early studies on the MORB (Spiegelman and Elliott, 1993; Lundstrom, 2003). Similar to the DM model, the ETM process could also occur during mantle upwelling in the hot zone or in the limb of the wedge (Fig. 8B).

\subsection{Constrains from experimental studies on mantle melting}

Successful application of in-growth melting models depends on not only the consistence of modelling results with U-series observations, but also the reasonableness of geology background the model is based on. The first factor that needs to be considered is the location of melting zone, which can be constrained by chemical composition of subduction zone lavas and thermal structure of the mantle wedge. Experimental studies have shown that the last equilibration between primitive subduction zone lavas $(\mathrm{Mg \#} \sim 70)$ and mantle peridotites could have taken place at $\sim 1$

GPa and $1100-1500{ }^{\circ} \mathrm{C}$, close to the crust-mantle boundary beneath volcanoes (Grove et al., 2012). Such P-T conditions establish the upper limits of melting zone, which is far away from the slab-wedge boundary (Abers et al., 2006).

Distribution and transport of $\mathrm{H}_{2} \mathrm{O}$ adds further controls on melting processes of the mantle (Gill, 1981; Grove et al., 2006; Cagnioncle et al., 2007). Observations of peridotites from the Franciscan mélange indicate that slab-derived $\mathrm{SiO}_{2}$-rich hydrous fluids were first delivered to the wedge, forming serpentine and talc at $450-500^{\circ} \mathrm{C}$ 
(King et al., 2003). Experimental work also shows that fluid-peridotite interaction above the slab boundary could produce a chlorite zone (Grove et al., 2009). The water-rich mineral zone is advected to greater depths following the corner flow and finally breaks down to release water into a vapour-saturated melt. Such melt ascends and transports water to shallower level due to buoyancy, dissolving more peripheral peridotites and increasing $\mathrm{SiO}_{2}$ content and mass of the melt (Grove et al., 2009).

Because the melting extent of the mantle is dominantly controlled by its water content and temperature exceeding the wet peridotite solidus (Davies and Bickle, 1991; Grove et al., 2006; Cagnioncle et al., 2007; Grove et al., 2012), the majority of melts are most likely produced in the hot zone of the mantle wedge (e.g., the hot nose as defined in Grove et al. (2012)), not the area right above the slab-wedge interface, e.g., the blue zones for FM and DM in Fig. 8. Therefore, the ETM or DM in the hot zone are more likely responsible for U-series disequilibria in subduction zone lavas, while the FM model will not be further considered in the following modelling.

\subsection{Simulating U-series disequilibria using in-growth melting models}

Because global arcs are quite different in convergent rates, thermal structure, and fertility of the mantle wedge (Gill, 1981), it is challenging to provide a uniform in-growth model to accurately reproduce the U-series disequilibria in all subduction zone lavas. Furthermore, many key parameters (including porosity, melting rate, and partition coefficients) are not well constrained, resulting in large uncertainties in the modelling results. Therefore, although the observations can be well re-produced by the melting models using appropriate parameters, the model outputs cannot be 
literally taken as the ultimate quantitative explanation for the observations. Instead, we would rather vary some key parameters of the model, trying to sort out useful information about how the subduction zone works to produce U-series disequilibria.

Because the DM model can produce essentially indistinguishable disequilibrium signatures to the ETM model when similar parameters are applied (Dosseto et al., 2003; Huang and Lundstrom, 2007), we only plot the results of the ETM model with varying porosity, $f \mathrm{O}_{2}$, and initial status of the mantle source in Figure 9. A few important modelling results for parent-daughter disequilibria are highlighted here.

${ }^{230}{ }^{\mathrm{Th}}-{ }^{238} \mathrm{U}$ data: $\left({ }^{230} \mathrm{Th}\right) /\left({ }^{238} \mathrm{U}\right)$ is sensitive to ${ }^{\mathrm{mineral} / \mathrm{melt}} \mathrm{D}_{\mathrm{U} / \mathrm{Th}}$, which varies with residual minerals and $f \mathrm{O}_{2}$ during partial melting. If garnet controls fractionation of $\mathrm{U}$ and Th, mantle-derived melts may have ${ }^{230} \mathrm{Th}$ excess over ${ }^{238} \mathrm{U}$ because of the higher ${ }^{\text {garnet } / \text { melt }} \mathrm{D}_{\mathrm{U}}$ than ${ }^{\text {garnet } / \mathrm{melt}} \mathrm{D}_{\mathrm{Th}}$ (Beattie, 1993; Blundy and Wood, 2003). Given that the garnet is preferentially stable in the mantle at high pressure, deeper melting beneath the thicker crust implies a more important role of garnet in controlling element partitioning, which is consistent with the higher proportion of ${ }^{230} \mathrm{Th}$ excess and higher $\mathrm{La} / \mathrm{Y}$ in the CMV lavas than that in island arc lavas (Fig. 10). Increasing $f \mathrm{O}_{2}$ can decrease ${ }^{\text {mineral/melt }} D_{U / T h}$ (Beattie, 1993; Lundstrom et al., 1994), which may decrease the net $\left({ }^{230} \mathrm{Th}\right) /\left({ }^{238} \mathrm{U}\right)$ in the final melt as shown in the variation from the curve $\mathrm{b}$ to $\mathrm{c}$ (Fig. 9A). If the mantle source has ${ }^{238} \mathrm{U}$ excess such as the curve $\mathrm{d}$ in Fig. 9A (Turner et al., 2011), comparison of d with c (with the source in secular equilibrium) shows that the source disequilibria can increasingly contribute to the melt when the melting rate increases. 
${ }^{231} \mathrm{~Pa}^{235} \mathrm{U}$ data: Because ${ }^{\text {mineral/melt }} \mathrm{D}_{\mathrm{U} / \mathrm{Pa}}$ is believed to be much higher than ${ }^{\text {mineral/melt }} \mathrm{D}_{\mathrm{U} / \mathrm{Th}}$ (Lundstrom et al., 1994; Blundy and Wood, 2003), $\left({ }^{231} \mathrm{~Pa}\right) /\left({ }^{235} \mathrm{U}\right)$ in the melt is more sensitive to the melting rate than $\left({ }^{230} \mathrm{Th}\right) /\left({ }^{238} \mathrm{U}\right)$. All ETM models produce higher ${ }^{231} \mathrm{~Pa}$ excess with decreasing melting rate (Fig. 9), which could be related to lowering the convergent rates if the mass of melt depends on subduction-driven dehydration and the rate of peridotite entering the melting zone (Turner et al., 2006; Huang and Lundstrom, 2007). The contribution of initial source disequilibrium to the $\left({ }^{231} \mathrm{~Pa}\right) /\left({ }^{235} \mathrm{U}\right)$ in the melt could be significant if the melting rate is large, owing to the short residence time in the melting zone. Notably, ${ }^{231} \mathrm{~Pa}$ deficit in the mantle source is required to explain the ${ }^{231} \mathrm{~Pa}$ deficit in the Tonga-Kermadec lavas.

${ }^{226} \mathrm{Ra}-{ }^{230} \mathrm{Th}$ data: $\left({ }^{226} \mathrm{Ra}\right) /\left({ }^{230} \mathrm{Th}\right)$ provides tighter temporal constrains than the $\left({ }^{231} \mathrm{~Pa}\right) /\left({ }^{235} \mathrm{U}\right)$ and $\left({ }^{230} \mathrm{Th}\right) /\left({ }^{238} \mathrm{U}\right)$ systematics because of the shorter $\tau_{1 / 2}$ of ${ }^{226} \mathrm{Ra}$. Modelling using variable porosities (e.g., $2 \%$ in curve a versus $1 \%$ in curve b) produces distinct $\left({ }^{226} \mathrm{Ra}\right) /\left({ }^{230} \mathrm{Th}\right)$, showing that $\left({ }^{226} \mathrm{Ra}\right) /\left({ }^{230} \mathrm{Th}\right)$ is sensitive to the porosity of the melting zone (Fig. 9B). This is important for understanding the extreme ${ }^{226} \mathrm{Ra}$ excess in the arc lavas (e.g., Tonga-Kermadec and Marianas) and the Manus back arc basin basalts (BABB). An in-growth melting model using a small porosity $(1 \%)$ was also adopted to explain the high $\left({ }^{226} \mathrm{Ra}\right) /\left({ }^{230} \mathrm{Th}\right)$ (up to 5.55) in the Manus BABB (Beier et al., 2010). Because the BABB are horizontally away from the New Britain volcanic front by a few hundred kilometers (Beier et al., 2010), the initial ${ }^{226} \mathrm{Ra}$ excess in the mantle source caused by slab-components should have decayed 
away during mantle convection. Thus the ${ }^{226} \mathrm{Ra}$ excesses in the Manus BABB are unlikely to be inherited from the source modified by Ra-rich fluids. Similarly, the high ${ }^{226} \mathrm{Ra}$ excess in island arc lavas should not be simply regarded as the fluid evidence either. Although it is not exactly clear why the Tonga-Kermadec and Marianas lavas have higher ${ }^{226} \mathrm{Ra}$ excess than the others, the ETM model using a porosity of $1 \%$ can reproduce such signature (Turner et al., 2000; Turner et al., 2001). Strictly speaking, the necessity of inheriting the source features only depends on whether ${ }^{231} \mathrm{~Pa}$ deficit exists in subduction zone lavas.

One of the problems in the in-growth melting models is that the required low porosity $(\sim 1-2 \%)$ is not consistent with geophysical and experimental observations (Faul, 2001; Connolly et al., 2009). By assuming that high porosity channels may drain and extract melt from ambient low porosity mantle, hybrid "two porosity" models have been proposed to reconcile such discrepancy in generating U-series disequilibria in MORB (Spiegelman and Elliott, 1993; Kelemen et al., 1997; Lundstrom, 2000). Although melting of the wet mantle wedge is different compared with the process of dry mantle melting beneath the mid-ocean ridge, the mechanism for generating U-series disequilibria could be similar.

\section{Temporal constrains of magmatism in convergent margins}

\subsection{The effect of magma differentiation on U-series data}

Most subduction zone lavas have experienced different extents of magma differentiation. The correlations of $\mathrm{SiO}_{2}$, a common differentiation index, is plotted with Th-Sr-Ba contents and U-series data of subduction zone lavas in Fig. 11. Th 
content increases and $\mathrm{Sr}$ decreases with increasing $\mathrm{SiO}_{2}$ (Fig. 11A-11C), indicating that $\mathrm{Th}$ is incompatible, but $\mathrm{Sr}$ is compatible during magma differentiation in the crust. The ranges of $\mathrm{Ba}$ content for island arc and the CMV lavas decrease with increasing $\mathrm{SiO}_{2}$. U/Th of subduction zone lavas do not clearly correlate to $\mathrm{SiO}_{2}$ content and they are generally higher than the average continental crust (Fig. 11D) (Rudnick and Gao, 2003). $\mathrm{Ba} / \mathrm{Th}$ and $\mathrm{Sr} / \mathrm{Th}$ are also higher than the crustal values with a large variation in low $\mathrm{SiO}_{2}$ samples (Fig. $11 \mathrm{E}$ and $11 \mathrm{~F}$ ), reflecting the variable slab contributions to the metasomatized mantle. Notably, the variation ranges of $\mathrm{Ba} / \mathrm{Th}$ and $\mathrm{Sr} / \mathrm{Th}$ dramatically shrink with increasing $\mathrm{SiO}_{2}$, owing to the effect of crustal contamination and mineral crystallization. Therefore, these two ratios are not reliable indices of slab fluids.

As mentioned earlier, the MAC process in the crust can significantly affect the U-series disequilibria developed from the mantle (Price et al., 2007; Huang et al., 2008; Price et al., 2010). Specifically, mixing old crustal materials may decrease the extent of disequilibria (Reubi et al., 2011); crystallization of minerals, where U-series nuclides are not highly incompatible (such as $\mathrm{Ra}$ in amphibole and $\mathrm{U}$ in zircon), which could also modify disequilibrium in differentiated magma (Garrison et al., 2006); and most importantly, ageing within the magma chamber, which could dramatically eliminate the primary U-series disequilibrium signatures (Huang et al., 2008).

On the basis of elemental composition variations, we can now better understand the effect of magma differentiation on U-series disequilibria. $\left({ }^{230} \mathrm{Th}\right) /\left({ }^{238} \mathrm{U}\right)$ and 
$\left({ }^{226} \mathrm{Ra}\right) /\left({ }^{230} \mathrm{Th}\right)$ of subduction zone lavas merge to unity with increasing $\mathrm{SiO}_{2}$ (Fig. $11 \mathrm{G}$ and $11 \mathrm{H}$ ); The CMV lavas are more so than the island arc lavas, likely reflecting the longer duration of magma storage and more crustal assimilation in the thick continental crust than in thin oceanic crust (Condomines et al., 2003; Garrison et al., 2006; Walker et al., 2007). There is no $\left({ }^{231} \mathrm{~Pa}\right) /\left({ }^{235} \mathrm{U}\right)$ data for lavas with $\mathrm{SiO}_{2}>70 \mathrm{wt} \%$ (Fig. 11I), but it can be predicted that the high $\mathrm{SiO}_{2}$ samples should be more likely in ${ }^{231} \mathrm{~Pa}-{ }^{235} \mathrm{U}$ equilibrium. One important implication is that inheritance of mantle source signatures, if any, should be better observed in less evolved subduction zone lavas.

\subsection{Timescale for magmatism in the crust and mantle}

After considering the complicated factors from slab subduction to magma eruption which can modify U-series disequilibria in erupted lavas, the temporal constrains on flux transfer and magmatism in the convergent margins can now be integrated (Fig. 12).

Metasomatism at the slab-wedge boundary: After slab materials (hydrous fluid and sediment melts) metasomatize the overlying wedge at the cold slab-wedge boundary, the slab signature is sent to the melting zone with mantle convection. Timescale for such a process cannot be constrained by U-series data except for the Tonga-Kermadec arc, where the ${ }^{231} \mathrm{~Pa}$ deficit requires $5 \tau_{1 / 2}$ of ${ }^{231} \mathrm{~Pa}(\sim 160 \mathrm{ka})$. Observation of ${ }^{10} \mathrm{Be}\left(\tau_{1 / 2}=1.5 \mathrm{Ma}\right)$ in subduction zone lavas suggests that metasomatism should happen within several Ma (Sigmarsson et al., 1990; Sigmarsson et al., 2002; George et al., 2003).

Melting in the hot zone: In-growth melting suggests that the timescale of melting 
in the hot zone should be at least comparable to the $\tau_{1 / 2}$ of short-lived nuclides. Depending on melting rate and the length of melting zone, such a process could take at least a few $\tau_{1 / 2}$ of ${ }^{231} \mathrm{~Pa}$ as required by most young lavas with ${ }^{231} \mathrm{~Pa}$ excess. Again, the exceptional ${ }^{231} \mathrm{~Pa}$ deficit in the Tonga-Kermadec lavas may imply that the timescale could be down to a few $\tau_{1 / 2}$ of ${ }^{226} \mathrm{Ra}$.

Storage in the crust: Timescale of the magma storage can be constrained by the U-series disequilibria preserved in lavas and minerals. For instance, observation of ${ }^{226} \mathrm{Ra}$ excess suggests that such a timescale should be within a few millennia (Turner et al., 2000; Huang et al., 2011). Recharge of fresh mantle-derived magma and partial melting in the crust may help to maintain the disequilibria for a much longer duration; up to 300 ka (Condomines et al., 2003; Dufek and Cooper, 2005; Asmerom et al., 2005; Cooper and Kent, 2014).

\section{Future work}

U-series disequilibria of subduction zone lavas have provided a plethora of messages in the last two decades which help to unravel how the mass flux is transferred from the slabs to the overlying mantle wedge. However, there are still many questions of this field requiring further exploration to improve the applications of U-series data. As shown in Fig. 4 and SOM Table 1, available datasets of primitive and well-dated subduction zone lavas are still rare. There is much less ${ }^{231} \mathrm{~Pa}$ data than ${ }^{238} \mathrm{U}_{-}{ }^{230} \mathrm{Th}^{226} \mathrm{Ra}$ data, especially in the Tonga-Kermadec arc. Studies on lavas erupted from a single volcano, such as the case studies of S. Lesser Antilles (Huang et al., 2011) and Volcán Llaima, Chile (Reubi et al., 2011), will be especially useful to filter 
out the effect of crustal modification and obtain the signatures developed from the mantle.

Furthermore, melting models, which take into account complicated thermal structure and geophysical observations, will provide important tectonic links for the U-series disequilibria in the subduction zone systems. Forward modeling combining geochemistry, geophysics, and geology has great potential to constrain subduction zone processes. Finally, experimental studies on partitioning of U-series nuclides among minerals (especially accessory minerals), melts, and fluids at the physical and chemical conditions of the subduction zones are also necessary for better melting models.

\section{Conclusions}

Understanding the formation of U-series disequilibria of subduction zone lavas is critical for the temporal constraints on slab-flux transfer and magmatism in convergent margins. A few conclusions can be drawn:

(1) After filtering out the effect of magma differentiation on U-series disequilibria, the positive correlations of $\left({ }^{226} \mathrm{Ra}\right) /\left({ }^{230} \mathrm{Th}\right)$ with $\mathrm{Sr} / \mathrm{Th}$ and $\mathrm{Ba} / \mathrm{Th}$ are not observed in subduction zone basalts, relaxing the key connection between slab-fluids and ${ }^{226} \mathrm{Ra}$ excess in lavas. Overwhelming ${ }^{231} \mathrm{~Pa}$ excess cannot be produced by slab melting or dehydration with a zircon-free residue because it conflicts with the $\mathrm{Zr}$-Hf depletions in subduction zone lavas.

(2) In-growth melting in the mantle followed by crustal modification can explain the U-series disequilibria in most of the subduction zone lavas, while inheritance of 
the source features metasomatized by U-rich fluids is only needed for the ${ }^{231} \mathrm{~Pa}$ deficit in the few Tonga-Kermadec lavas.

(3) Thermal structure of convergent margins suggests that most melts and U-series disequilibria should be produced in the hot zone of the wedge, far from the slab-wedge boundary.

(4) Combining the timescales of slab-flux transfer and magmatism in the convergent margins to produce U-series disequilibria in subduction zone lavas, there is likely a range from a few thousand to a few hundred thousand years.

\section{Acknowledgments}

This work is supported by the National Science Foundation of China (41503001, 41325011, and 41173031), the 111 Project, and the Fundamental Research Funds for the Central Universities. We thank Klaus Mezger for the editorial handling and comments. Comments from two anonymous reviewers greatly improved this manuscript. We also thank Alex Valentine for polish English of this manuscript. 


\section{Figure captions}

Figure 1. Locations of subduction zone lavas investigated for U-series disequilibria in the literature. Red circles are continental margin volcanoes (CMV) and blue stars are island arcs.

Figure 2. Plot of $\left({ }^{238} \mathrm{U}\right) /\left({ }^{232} \mathrm{Th}\right)$ versus $\left({ }^{230} \mathrm{Th}\right) /\left({ }^{232} \mathrm{Th}\right)$ for the global island arc and CMV lavas. All data use the initial disequilibria corrected for decay since eruption. Both ${ }^{238} \mathrm{U}$ excess and deficit can be observed in lavas from the same subduction zone. Data are from SOM Table 1 and the references are in SOM Table 2.

Figure 3. Correlations of $\left({ }^{231} \mathrm{~Pa}\right) /\left({ }^{235} \mathrm{U}\right)$ with $(\mathrm{A})\left({ }^{226} \mathrm{Ra}\right) /\left({ }^{230} \mathrm{Th}\right),(\mathrm{B})\left({ }^{230} \mathrm{Th}\right) /\left({ }^{238} \mathrm{U}\right)$, and $(\mathrm{C})\left({ }^{226} \mathrm{Ra}\right) /\left({ }^{238} \mathrm{U}\right)$ for subduction zone lavas. Most lavas have ${ }^{226} \mathrm{Ra}$ and ${ }^{231} \mathrm{~Pa}$ excesses, not supporting the origin of U-series disequilibria from a recent addition of Ra-U rich fluid from the slabs (Fig. 3A and 3B). The CMV lavas show different U-series signature with island arc lavas. Data source is from SOM Table 1.

Figure 4. Distribution frequencies of (A) $\left({ }^{230} \mathrm{Th}\right) /\left({ }^{238} \mathrm{U}\right)$, (B) $\left({ }^{231} \mathrm{~Pa}\right) /\left({ }^{235} \mathrm{U}\right)$, and (C) $\left({ }^{226} \mathrm{Ra}\right) /\left({ }^{230} \mathrm{Th}\right)$ in the $\mathrm{CMV}$ and island arc lavas. Relative to the CMV, the island arcs have a higher proportion of lavas with ${ }^{238} \mathrm{U}$ excess and larger ranges of $\left({ }^{231} \mathrm{~Pa}\right) /\left({ }^{235} \mathrm{U}\right)$ and $\left({ }^{226} \mathrm{Ra}\right) /\left({ }^{230} \mathrm{Th}\right)$. The size of the $\left({ }^{231} \mathrm{~Pa}\right) /\left({ }^{235} \mathrm{U}\right)$ dataset is much smaller than that of $\left({ }^{230} \mathrm{Th}\right) /\left({ }^{238} \mathrm{U}\right)$ and $\left({ }^{226} \mathrm{Ra}\right) /\left({ }^{230} \mathrm{Th}\right)$, likely due to analytical difficulty for ${ }^{231} \mathrm{~Pa}$. Data source is from SOM Table 1 .

Figure 5. $\left({ }^{226} \mathrm{Ra}\right) /\left({ }^{230} \mathrm{Th}\right)$ versus $\mathrm{Ba} / \mathrm{Th}, \mathrm{Sr} / \mathrm{Th}$, and $\left({ }^{238} \mathrm{U}\right) /\left({ }^{230} \mathrm{Th}\right)$ for the CMV lavas 
with $\mathrm{SiO}_{2}<52 \mathrm{wt} \%$ (A, B, and C) and $\mathrm{SiO}_{2}>52 \mathrm{wt} \%$ (D, E, and F). There is not positive correlation of $\left({ }^{226} \mathrm{Ra}\right) /\left({ }^{230} \mathrm{Th}\right)$ with $\mathrm{Ba} / \mathrm{Th}, \mathrm{Sr} / \mathrm{Th}$, and $\left({ }^{238} \mathrm{U}\right) /\left({ }^{230} \mathrm{Th}\right)$ in lavas with $\mathrm{SiO}_{2}<52 \mathrm{wt} \%$. Instead, the positive correlations among "fluid indices" are shown in evolved lavas, such as in Kamchatka. Data are from SOM Table 1.

Figure 6. $\left({ }^{226} \mathrm{Ra}\right) /\left({ }^{230} \mathrm{Th}\right)$ versus $\mathrm{Ba} / \mathrm{Th}, \mathrm{Sr} / \mathrm{Th}$, and $\left({ }^{238} \mathrm{U}\right) /\left({ }^{230} \mathrm{Th}\right)$ for island arc lavas with $\mathrm{SiO}_{2}<52 \mathrm{wt} \%$ (A, B, and C) and $\mathrm{SiO}_{2}>52 \mathrm{wt} \%$ (D, E, and $\mathrm{F}$ ). When lavas are grouped by $\mathrm{SiO}_{2}$ content, $\left({ }^{226} \mathrm{Ra}\right) /\left({ }^{230} \mathrm{Th}\right)$ is not clearly correlated with $\mathrm{Ba} / \mathrm{Th}$, $\mathrm{Sr} / \mathrm{Th}$, and $\left({ }^{238} \mathrm{U}\right) /\left({ }^{230} \mathrm{Th}\right)$ in island arc basalts with $\mathrm{SiO}_{2}<52 \mathrm{wt} \%$. Data are from is from SOM Table 1.

Figure 7. Th/U versus $\mathrm{Zr} / \mathrm{Pa}$ for global subduction zone lavas. The Lesser Antilles lavas have lower $\mathrm{Zr} / \mathrm{Pa}$ than those from the Tonga-Kermadec arcs, not consistent with the trend of adding zircon-free fluids for the ${ }^{231} \mathrm{~Pa}$ excess in Lesser Antilles as suggested in Avanzinelli et al. (2012). Data are from SOM Table 1.

Figure 8. A, Cartoon showing flux melting (FM) induced by fluids from the subducted slab. FM likely occurs right above the slab-wedge boundary, requiring efficient focusing and extraction of melts in the convective mantle wedge. B, Conceptual diagram for dynamic melting (DM) and equilibrium transport melting (ETM) models. Although in-growth melting could take place above the slab-wedge boundary or the limb of the wedge, the hot zone may be the dominant location for mantle melting because of the maximum excess of temperature over the wet peridotite solidus (Grove et al., 2006; Grove et al., 2012). 
Figure 9. The ETM models with variable parameters to simulate U-series disequilibria. The models use basic equations from Spiegelman and Elliott (1993) and Lundstrom (2003). The bulk ${ }^{\text {solid/melt }} \mathrm{D}$ of U-series nuclides: U, 0.0052 (defined as $\left.\mathrm{D}_{\mathrm{U} 0}\right)$; Th, $0.0044 ; \mathrm{Pa}, 2.1^{*} 10^{-6}$; and $\mathrm{Ra}, 8.9^{*} 10^{-7}$, similar to the values used in Turner et al. (2006) and Huang et al. (2011). Modelling curve c, d, and e use a smaller $\mathrm{D}_{\mathrm{U}}\left(0.0026,1 / 2\right.$ of the $\left.\mathrm{D}_{\mathrm{U} 0}\right)$ to test the effect of high $\mathrm{fO}_{2}$ on $\left({ }^{231} \mathrm{~Pa}\right) /\left({ }^{235} \mathrm{U}\right)$ and $\left({ }^{230} \mathrm{Th}\right) /\left({ }^{238} \mathrm{U}\right)$. Porosities are fixed at $2 \%$ (a and e) or $1 \%$ (b, c, and d). The two gray arrows in Fig. 9A denote melting with garnet (grt) as the dominant residual mineral or at a higher $\mathrm{fO}_{2}$, respectively, while the arrow in Fig. 9B shows that decreasing porosity can dramatically increase the ${ }^{226} \mathrm{Ra}$ excess. For the purpose of illustrating the source effect, curve $d$ arbitrarily assumes that the mantle is in U-series disequilibrium with $\left({ }^{231} \mathrm{~Pa}\right) /\left({ }^{235} \mathrm{U}\right)=\left({ }^{230} \mathrm{Th}\right) /\left({ }^{238} \mathrm{U}\right)=0.8$ and $\left({ }^{226} \mathrm{Ra}\right) /\left({ }^{230} \mathrm{Th}\right)=6$. This is needed to reproduce the ${ }^{231} \mathrm{~Pa}$ deficit in some Tonga-Kermadec lavas (Bourdon et al., 1999). The symbols and numbers on the model curves represent melting rates with a unit of $\mathrm{kg} /\left(\mathrm{m}^{3} \cdot \mathrm{ka}\right)$.

Figure 10. Comparison of $\left({ }^{230} \mathrm{Th}\right) /\left({ }^{238} \mathrm{U}\right)$ and $\mathrm{La} / \mathrm{Y}$ of the $\mathrm{CMV}$ lavas with the island arc lavas. The CMV lavas have clearly higher La/Y than the island arc lavas, supporting a more important role of garnet in fractionating $\mathrm{U}$ and $\mathrm{Th}$.

Figure 11. Variation of Th-Sr-Ba contents (ppm), U/Th, Ba/Th, Sr/Th, and U-series disequilibria with $\mathrm{SiO}_{2}$ of subduction zone lavas. U-series data and other geochemical compositions are significantly modified with increasing extent of magma differentiation. The diamonds with numbers denote continental crust 
values (Rudnick and Gao, 2003): 1, lower crust; 2, middle crust; and 3, upper crust. Arc data are from SOM Table 1.

Figure 12. Schematic diagram of mass flux from the subducted slabs to overlying mantle wedge and crust. The main processes include releasing slab-fluids and melts, metasomatism, mantle convection, melting in the hot zone, MAC in the crust, and final eruption. U-series disequilibria of subduction zone lavas are dominantly controlled by mantle melting and crustal modification. 


\section{References:}

Abers, G.A., van Keken, P.E., Kneller, E.A., Ferris, A., Stachnik, J.C., 2006. Thermal structure of subduction zones constrained by seismic imaging: Implications for slab dehydration and wedge flow. Earth Planet. Sci. Lett., 241: 387- 397.

Ankney, M.E., Shirey, S.B., Hart, G.L., Bacon, C.R., Johnson C., 2016. Os and U-Th isotope signatures of arc magmatism near Mount Mazama, Crater Lake, Oregon. Earth Planet. Sci. Lett., 437: 25-34.

Asmerom, Y., DuFrane, S.A., Mukasa, S.B., Cheng, H., Edwards, R.L., 2005. Time scale of magma differentiation in arcs from protactinium-radium isotopic data. Geology, 33: 633-636.

Avanzinelli, R., Elliott, T., Tommasini, S., Conticelli, S., 2008. Constraints on the genesis of potassium-rich Italian volcanic rocks from U/Th disequilibrium. Journal of Petrology, 49(2): 195-223.

Avanzinelli, R., Prytulak, J., Skora, S., Heumann, A., Koetsier, G., Elliott, T., 2012. Combined ${ }^{238} \mathrm{U}-{ }^{230} \mathrm{Th}$ and ${ }^{235} \mathrm{U}-{ }^{231} \mathrm{~Pa}$ constraints on the transport of slab-derived material beneath the Mariana Islands. Geochim. Cosmochim. Acta, 92: 308-328.

Beattie, P., 1993. Uranium-thorium disequilibria and partitioning on melting of garnet peridotite. Nature, 363: 63-65.

Beier, C., Turner, S.P., Sinton, J.M., Gill, J.B., 2010. Influence of subducted components on back-arc melting dynamics in the Manus Basin. Geochem. Geophys. Geosyst., 11, Q0AC03. doi:10.1029/2010GC003037.

Black, S., Macdonald, R., DeVivo, B., Kilburn, C.R., Rolandi, G., 1998. U-series disequilibria in young (AD 1944) Vesuvius rocks: preliminary implications for magma residence times and volatile addition. Journal of Volcanology and Geothermal Research, 82(1): 97-111.

Blundy, J., Wood, B., 2003. Mineral-melt partitioning of Uranium, Thorium and their daughters. Reviews in Mineralogy and Geochemistry, 52: 59-123.

Bourdon, B., Sims, K., 2003. U-series constraints on intraplate basaltic magmatism. Reviews in Mineralogy and Geochemistry, 52: 215-254.

Bourdon, B., Turner, S., Allègre, C., 1999. Melting dynamics beneath the Tonga-Kermadec island arc inferred from 231Pa-235U systematics. Science, 286(5449): 2491-2493.

Bourdon, B., Turner, S., Dosseto, A., 2003. Dehydration and partial melting in subduction zones: constrains from U-series disequilibria. Journal of Geophysical Research, 108(B6): 2291.

Brenan, J.M., Shaw, H.F., Ryerson, F.J., Phinney, D.L., 1995. Experimental determination of trace-element partitioning between pargasite and a synthetic hydrous andesitic melt. Earth Planet. Sci. Lett., 135: 1-11.

Cagnioncle, A.-M., Parmentier, E.M., Elkins-Tanton, L.T., 2007. Effect of solid flow above a subducting slab on water distribution and melting at convergent plate boundaries. Journal of Geophysical Research, 112, B09402, doi:10.1029/2007JB004934.

Chabaux, F., Hémond, C., Allègre, C.J., 1999. 238U-230Th-226Ra disequilibria in 
the Lesser Antilles arc: implications for mantle metasomatism. Chem. Geol., 153(1): 171-185.

Condomines, M., Gauthier, P.J., Sigmarsson, O., 2003. Uranium Series Geochemistry. Timescales of magma chamber processes and dating of young volcanic rocks. Geochemical Society and Mineralogical Society of America. Reviews in Mineralogy and Geochemistry, 52: 125-174.

Connolly, J.A.D., Schmidt, M.W., Solferino, G., Bagdassarov, N., 2009. Permeability of asthenospheric mantle and melt extraction rates at mid-ocean ridges. Nature, 462: 209-212.

Cooper, K.M., Kent, A.J.R., 2014. Rapid remobilization of magmatic crystals kept in cold storage. Nature, 506: 480-483.

Davies, J.H., Bickle, M.J., 1991. A physical model for the volume and composition of melt produced by hydrous fluxing above subduction zone. Pilos. Trans. R. Soc. London, ser. A, 335: 355-364.

Dosseto, A., Bourdon, B., Joron, J.-L., Dupré, B., 2003. U-Th-Pa-Ra study of the Kamchatka arc: New constraints on the genesis of arc lavas. Geochim. Cosmochim. Acta, 67(15): 2857-2877.

Dosseto, A., Turner, S.P., Van-Orman, J.A., 2010. Timescales of Magmatic Processes: From Core to Atmosphere. ISBN: 978-1-4443-3260-5.

Dufek, J., Cooper, K.M., 2005. ${ }^{226} \mathrm{Ra} /{ }^{230} \mathrm{Th}$ excess generated in the lower crust: Implications for magma transport and storage time scales. Geology, 37: 833-836.

DuFrane, S.A., Turner, S., Dosseto, A., van Soest, M., 2009. Reappraisal of fluid and sediment contributions to Lesser Antilles magmas. Chem. Geol., 265: 272-278.

Elkins-Tanton, L.T., Grove, T.L., Donnelly-Nolan, J., 2001. Hot, shallow mantle melting under the Cascades volcanic arc. Geology, 29: 631-634.

Elliott, T., Plank, T., Zindler, A., White, W., Bourdon, B., 1997. Element transport from slab to volcanic front at the Mariana arc. Journal of Geophysical Research: Solid Earth (1978-2012), 102(B7): 14991-15019.

Faul, U.H., 2001. Melt retention and segregation beneathmid-ocean ridges. Nature, 410: $920-923$.

Feineman, M.D., DePaolo, D.J., 2003. Steady-state ${ }^{226} \mathrm{Ra} /{ }^{230} \mathrm{Th}$ disequilibrium in mantle minerals: implications for melt transport rates in island arcs. Earth Planet. Sci. Lett., 215(3-4): 339-355.

Garrison, J., Davidson, J., Reid, M., Turner, S., 2006. Source versus differentiation controls on U-series disequilibria: insights from Cotopaxi Volcano, Ecuador. Earth Planet. Sci. Lett., 244(3): 548-565.

George, R. et al., 2004. Chemical versus temporal controls on the evolution of tholeiitic and calc-alkaline magmas at two volcanoes in the Alaska-Aleutian arc. Journal of Petrology, 45(1): 203-219.

George, R. et al., 2003. Melting processes and fluid and sediment transport rates along the Alaska - Aleutian arc from an integrated $\mathrm{U}-\mathrm{Th}-\mathrm{Ra}-\mathrm{Be}$ isotope study. Journal of Geophysical Research: Solid Earth (1978-2012), 108(B5). 
Gill, J.B., 1981. Orogenic Andesites and Plate Tectonics, Springer-Verlag.

Grove, T.L., Chatterjee, N., Parman, S.W., Médard, E., 2006. The influence of $\mathrm{H}_{2} \mathrm{O}$ on mantle wedge melting. Earth Planet. Sci. Lett., 249: 74-89.

Grove, T.L., Till, C.B., Krawczynski, M.J., 2012. The role of $\mathrm{H}_{2} \mathrm{O}$ in subduction zone magmatism. Annu. Rev. Earth Planet. Sci., 40: 413-439.

Grove, T.L., Till, C.B., Lev, E., Chatterjee, N., Medard, E., 2009. Kinematic variables and water transport control the formation and location of arc volcanoes. Nature, 459: 694-697.

Heath, E., Macdonald, R., Belkin, H., Hawkesworth, C., Sigurdsson, H., 1998. Magmagenesis at Soufriere Volcano, St Vincent, Lesser Antilles Arc. Journal of Petrology, 39(10): 1721-1764.

Hermann, J., 2002. Allanite: thorium and light rare earth element carrier in subducted crust. Chem. Geol., 192: 289-306.

Hermann, J., Rubatto, D., 2009. Accessory phase control on the trace element signature of sediment melts in subduction zones. Chem. Geol., 265: 512-526.

Huang, F., Gao, L., Lundstrom, C.C., 2008. The effect of assimilation, fractional crystallization, and ageing on U-series disequilibria in subduction zone lavas. Geochim. Cosmochim. Acta, 72: 4136-4145.

Huang, F., Lundstrom, C.C., 2007. ${ }^{231} \mathrm{~Pa}$ excesses in arc volcanic rocks: constraint on melting rates at convergent margins. Geology, 35: 1007-1010.

Huang, F., Lundstrom, C.C., Sigurdsson, H., Zhang, Z., 2011. U-series disequilibria in Kick'em Jenny submarine volcano lavas: A new view of time-scales of magmatism in convergent margins. Geochim. Cosmochim. Acta, 75: 195-212.

Jagoutz, O., Kelemen, P.B., 2015. Role of arc processes in the formation of continental crust. Annu. Rev. Earth Planet. Sci., 43: 363-404.

Kelemen, P.B., Hirth, G., Shimizu, N., Spiegelman, M., Dick, H.J.B., 1997. Review of melt migration processes in the adiabatically upwelling mantle beneath oceanic spreading ridges. Philos. Trans. R. Soc., 355: 283-318.

Keppler, H., 1996. Constraints from partitioning experiments on the composition of subduction zone fluids. Nature, 380: 237-240.

Keppler, H., Wyllie, P.J., 1990. Role of fluids in transport and fractionation of uranium and thorium in magmatic processes. Nature, 348: 531-533.

King, R.L., Kohn, M.J., Eiler, J.M., 2003. Constraints on the petrologic structure of the subduction zone slab-mantle interface from Franciscan Complex exotic ultramafic blocks. GSA Bulletin, 115: 1097-1109.

Koornneef, J.M., Stracke, A., Aciego, S., Reubi, O., Bourdon, B., 2010. A new method for U-Th-Pa-Ra separation and accurate measurement of ${ }^{234} \mathrm{U}-{ }^{230} \mathrm{Th}-{ }^{231} \mathrm{~Pa}-{ }^{226} \mathrm{Ra}$ disequilibria in volcanic rocks by MC-ICPMS. Chem. Geol., 277: 30-41.

LaTourrette, T., Hervig, R.L., Holloway, J.R., 1995. Trace element partitioning between amphibole, phlogopite, and basanite melt. Earth Planet. Sci. Lett., 135: $13-30$.

Lundstrom, C.C., 2000. Models of U-series disequilibria generation in MORB: the effects of two scales of melt porosity. Physics of the Earth and Planetary 
Interiors, 121: 189-204.

Lundstrom, C.C., 2003. Uranium Series Disequilibria in Mid-Ocean Ridge Basalts: observations and models of basalt genesis. Reviews in Mineralogy and Geochemistry, 52: 175-214.

Lundstrom, C.C. et al., 1994. Compositional controls on the partitioning of U, Th, Ba, $\mathrm{Pb}, \mathrm{Sr}$ and $\mathrm{Zr}$ between clinopyroxene and haplobasaltic melts: Implications for uranium series disequilibria in basalts. Earth Planet. Sci. Lett., 128: 407-423.

McKenzie, D., 1985. ${ }^{230} \mathrm{Th}^{238} \mathrm{U}$ disequilibrium and the melting process beneath ridge axes. Earth Planet. Sci. Lett., 72: 149-157.

McKenzie, D., 2000. Constraints on melt generation and transport from U-series activity ratios. Chem. Geol., 162: 81-94.

Mitchell, Euan C. and Asmerom, Y., 2011. U-series isotope systematics of mafic magmas from central Oregon: Implications for fluid involvement and melting processes in the Cascade arc. Earth Planet. Sci. Lett., 312: 378 - 389.

Newman, S., Macdougall, J., Finkel, R., 1984. 230Th-238U disequilibrium in island arcs: evidence from the Aleutians and the Marianas. Nature, 308: 268-270.

Pickett, D.A., Murrell, M.T., 1997. Observations of ${ }^{231} \mathrm{~Pa} /{ }^{235} \mathrm{U}$ disequilibrium in volcanic rocks. Earth Planet. Sci. Lett., 148(1): 259-271.

Plank, T., Langmuir, C.H., 1998. The chemical composition of subducting sediment and its consequences for the crust and mantle. Chem. Geol., 145: 325-394.

Price, R.C. et al., 2007. U-Th-Ra fractionation during crustal-level andesite formation at Ruapehu volcano, New Zealand. Chem. Geol., 244(3): 437-451.

Price, R.C. et al., 2010. Crustal and mantle influences and U-Th-Ra disequilibrium in andesitic lavas of Ngauruhoe volcano, New Zealand. Chem. Geol., 277: 355-373.

Regelous, M., Collerson, K., Ewart, A., Wendt, J., 1997. Trace element transport rates in subduction zones: evidence from $\mathrm{Th}, \mathrm{Sr}$ and $\mathrm{Pb}$ isotope data for Tonga-Kermadec arc lavas. Earth Planet. Sci. Lett., 150(3): 291-302.

Reubi, O. et al., 2011. Assimilation of the plutonic roots of the Andean arc controls variations in U-series disequilibria at Volcan Llaima, Chile. Earth Planet. Sci. Lett., 303(1): 37-47.

Reubi, O., Sims, K.W., Bourdon, B., 2014. ${ }^{238} \mathrm{U}^{230}$ Th equilibrium in arc magmas and implications for the time scales of mantle metasomatism. Earth Planet. Sci. Lett., 391: 146-158.

Rubatto, D., Hermann, J., 2007. Experimental zircon/melt and zircon/garnet trace element partitioning and implications for the geochronology of crustal rocks. Chem. Geol. , 241: 38-61.

Rudnick, R.L., 1995. Making continental crust. Nature, 378: 571-578.

Rudnick, R.L., Gao, S., 2003. Composition of the Continental Crust, pp 1-64. In the Crust (ed. R.L. Rudnick) Vol. 3 Treatise on Geochemistry (eds. H.D. Holland and K.K. Turekian), Elsevier-Pergamon, Oxford.

Schmidt, M.W., Poli, S., 1998. Experimentally based water budgets for dehydrating slabs and consequences for arc magma generation. Earth Planet. Sci. Lett., 163: 361-379. 
Schmitt, A.K., 2007. Ion microprobe analysis of $\left({ }^{231} \mathrm{~Pa}\right) /\left({ }^{235} \mathrm{U}\right)$ and an appraisal of protactinium partitioning in igneous zircon. Am. Mineral., 92: 691-694.

Sigmarsson, O., Chmeleff, J., Morris, J., Lopez-Escobar, L., 2002. Origin of ${ }^{226} \mathrm{Ra}-{ }^{230} \mathrm{Th}$ disequilibria in arc lavas from southern Chile and implications for magma transfer time. Earth Planet. Sci. Lett., 196(3): 189-196.

Sigmarsson, O., Condomines, M., Morris, J., Harmon, R., 1990. Uranium and 10Be enrichments by fluids in Andean arc magmas.

Sillitoe, R.H., 2010. Porphyry Copper Systems. Economic Geology, 105: 3-41.

Sims, K.W.W. et al., 2008. ${ }^{238} \mathrm{U}_{-}{ }^{230} \mathrm{Th}_{-}{ }^{226} \mathrm{Ra}_{-}{ }^{210} \mathrm{~Pb}-{ }^{210} \mathrm{Po},{ }^{232} \mathrm{Th}^{-28} \mathrm{Ra}$, and ${ }^{235} \mathrm{U}^{231} \mathrm{~Pa}$ constraints on the ages and petrogenesis of Vailulu'u and Malumalu Lavas, Samoa. G-Cubed, Q04003, doi:10.1029/2007 GC001651.

Spiegelman, M., 1996. Geochemical consequences of melt transport in 2-D: the sensitivity of trace elements to mantle dynamics. Earth Planet. Sci. Lett., 139: 115-132.

Spiegelman, M., Elliott, T., 1993. Consequences of melt transport for uranium series disequilibrium in young lavas. Earth Planet. Sci. Lett., 118: 1-20.

Thomas, R.B., Hirschmann, M.M., Cheng, H., Reagan, M.K., Edwards, R.L., 2002. $\left({ }^{231} \mathrm{~Pa} /{ }^{235} \mathrm{U}\right)-\left({ }^{230} \mathrm{Th} /{ }^{238} \mathrm{U}\right)$ of young mafic volcanic rocks from Nicaragua and Costa Rica and the influence of flux melting on U-series systematics of arc lavas. Geochim. Cosmochim. Acta, 66(24): 4287-4309.

Touboul, M., Bourdon, B., Villemant, B., Boudon, G., Joron, J.-L., 2007. ${ }^{238} \mathrm{U}-{ }^{230} \mathrm{Th}-{ }^{226} \mathrm{Ra}$ disequilibria in andesitic lavas of the last magmatic eruption of Guadeloupe Soufriere, french Antilles: Processes and timescales of magma differentiation. Chem. Geol., 246(3): 181-206.

Turner, S., Bourdon, B., Gill, J., 2003a. U-Series isotopes and magma genesis at convergent margins. Review in Mineralogy and Geochemistry, 52: 255-315.

Turner, S., Bourdon, B., Hawkesworth, C., Evans, P., 2000. ${ }^{226} \mathrm{Ra}-{ }^{230} \mathrm{Th}$ evidence for multiple dehydration events, rapid melt ascent and the time scales of differentiation beneath the Tonga-Kermadec island arc. Earth Planet. Sci. Lett., 179(3): 581-593.

Turner, S. et al., 2011. Recent contribution of sediments and fluids to the mantle's volatile budget. Nature Geoscience, 5: 50-54.

Turner, S., Evans, P., Hawkesworth, C., 2001. Ultrafast source-to-surface movement of melt at island arcs from ${ }^{226} \mathrm{Ra}^{2}{ }^{230} \mathrm{Th}$ systematics. Science, 292(5520): 1363-1366.

Turner, S. et al., 2003b. Rates and processes of potassic magma evolution beneath Sangeang Api volcano, East Sunda arc, Indonesia. Journal Petrol. 44(3): 491-515.

Turner, S. et al., 1997. ${ }^{238} \mathrm{U}_{-}{ }^{230} \mathrm{Th}$ disequilibria, magma petrogenesis, and flux rates beneath the depleted Tonga-Kermadec island arc. Geochim. Cosmochim. Acta, 61(22): 4855-4884.

Turner, S. et al., 1996. U-series isotopes and destructive plate margin magma genesis in the Lesser Antilles. Earth Planet. Sci. Lett., 142(1): 191-207.

Turner, S., Regelous, M., Hawkesworth, C., Rostami, K., 2006. Partial melting 
processes above subducting plates: Constraints from ${ }^{231} \mathrm{~Pa}^{235} \mathrm{U}$ disequilibria Geochim. Cosmochim. Acta, 70( ): 480-503.

Turner, S., Sims, K.W., Reagan, M., Cook, C., 2007. A ${ }^{210} \mathrm{~Pb}-{ }^{226} \mathrm{Ra}^{-}{ }^{230} \mathrm{Th}-{ }^{238} \mathrm{U}$ study of Klyuchevskoy and Bezymianny volcanoes, Kamchatka. Geochim. Cosmochim. Acta, 71(19): 4771-4785.

Walker, J.A. et al., 2007. U - series disequilibria in Guatemalan lavas, crustal contamination, and implications for magma genesis along the Central American subduction zone. Journal Geophysical Res.: Solid Earth (1978-2012), 112(B6).

Wende, A.M., Johnson, C.M., Beard, B.L., 2015. Tracing changes in mantle and crustal influences in individual cone-building stages at Mt. Shasta using U-Th and Sr isotopes. Earth Planet. Sci. Lett., 428: 11-21.

Yokoyama, T., Kobayashi, K., Kuritani, T., Nakamura, E., 2003. Mantle metasomatism and rapid ascent of slab components beneath island arcs: Evidence from ${ }^{238} \mathrm{U}-{ }^{230} \mathrm{Th}-{ }^{226} \mathrm{Ra}$ disequilibria of Miyakejima volcano, Izu arc, Japan. Journal of Geophysical Res.: Solid Earth (1978-2012), 108(B7).

Zellmer, G., Turner, S., Hawkesworth, C., 2000. Timescales of destructive plate margin magmatism: new insights from Santorini, Aegean volcanic arc. Earth Planet. Sci. Lett., 174(3): 265-281. 


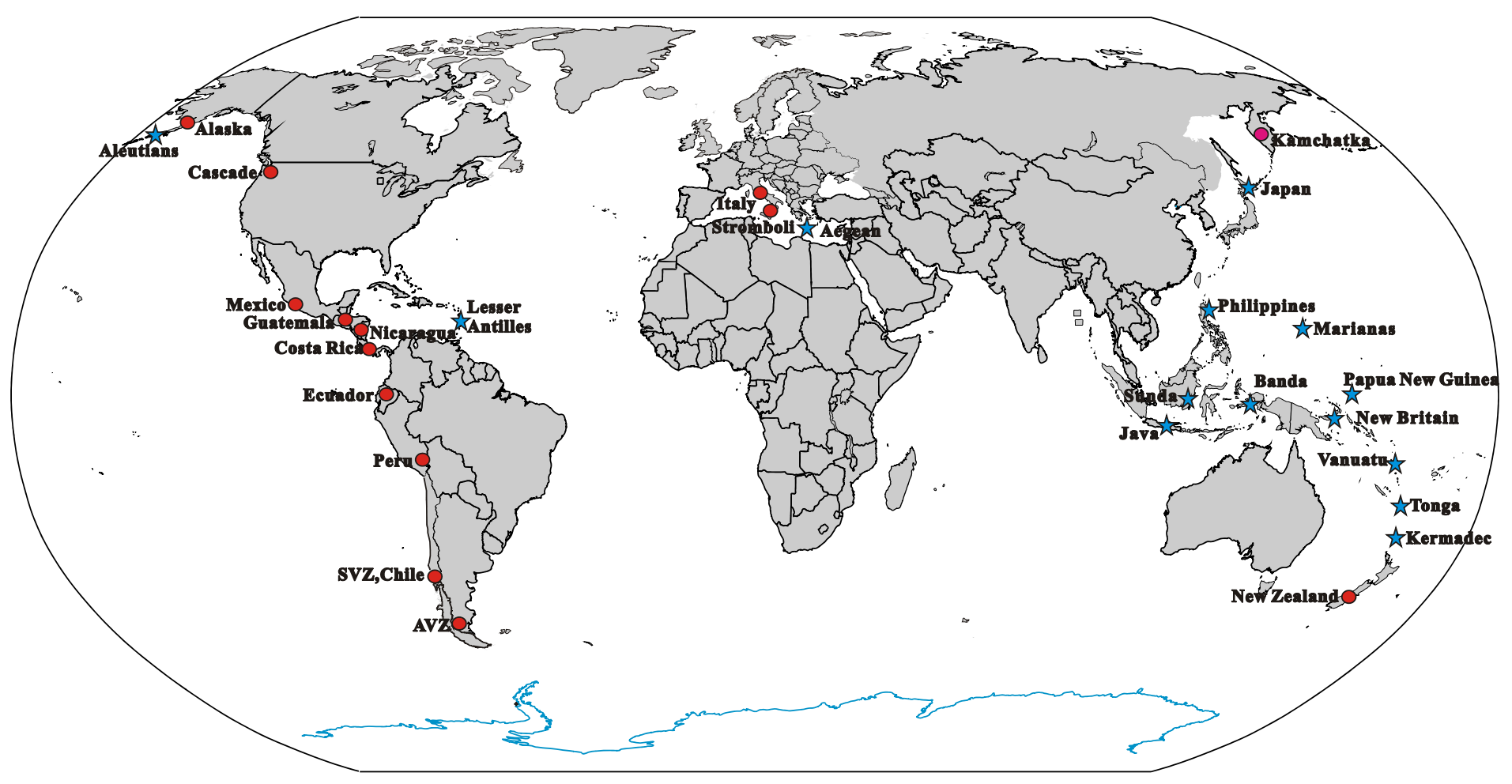

Fig. 1 

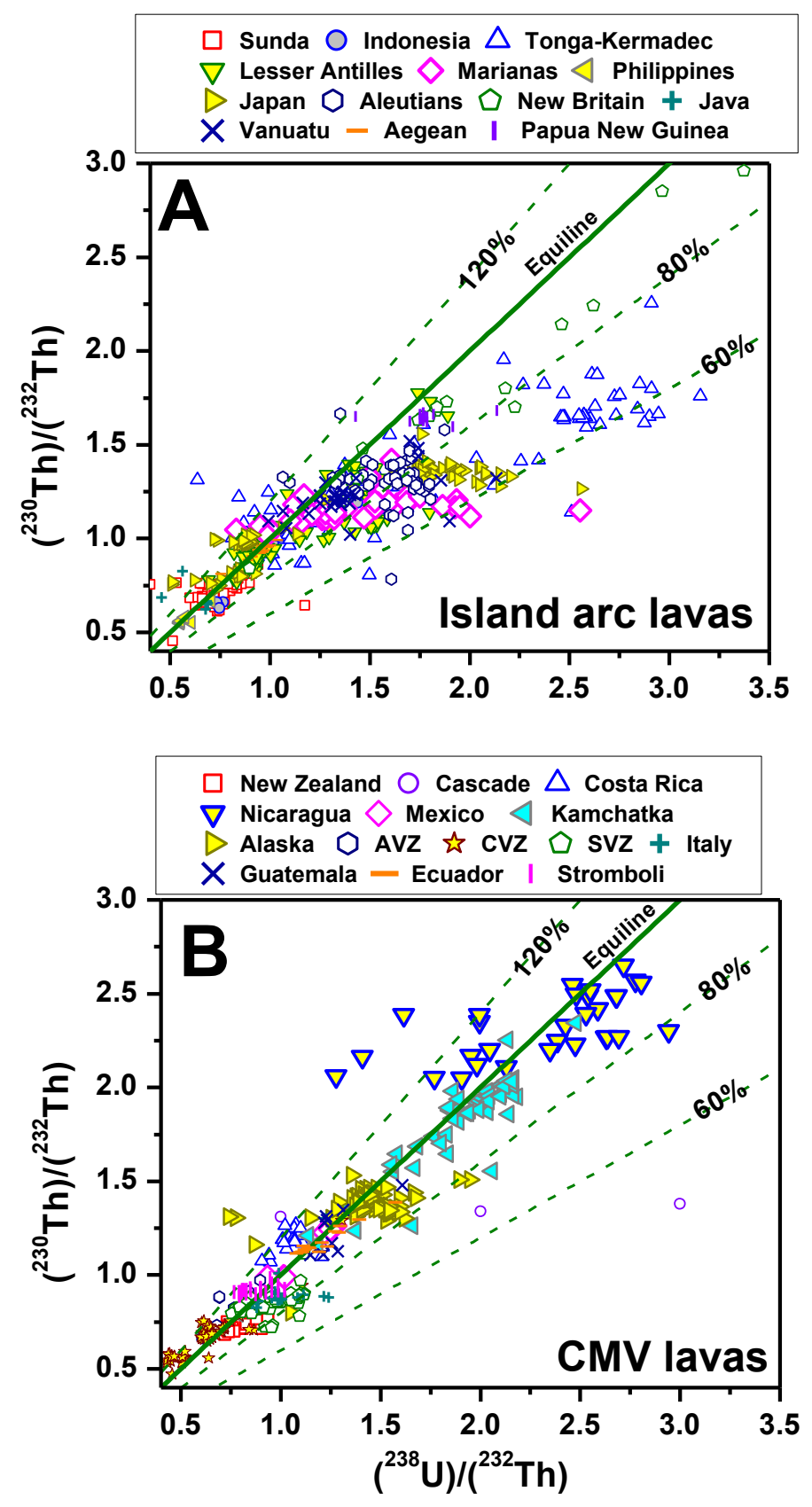

Fig. 2 


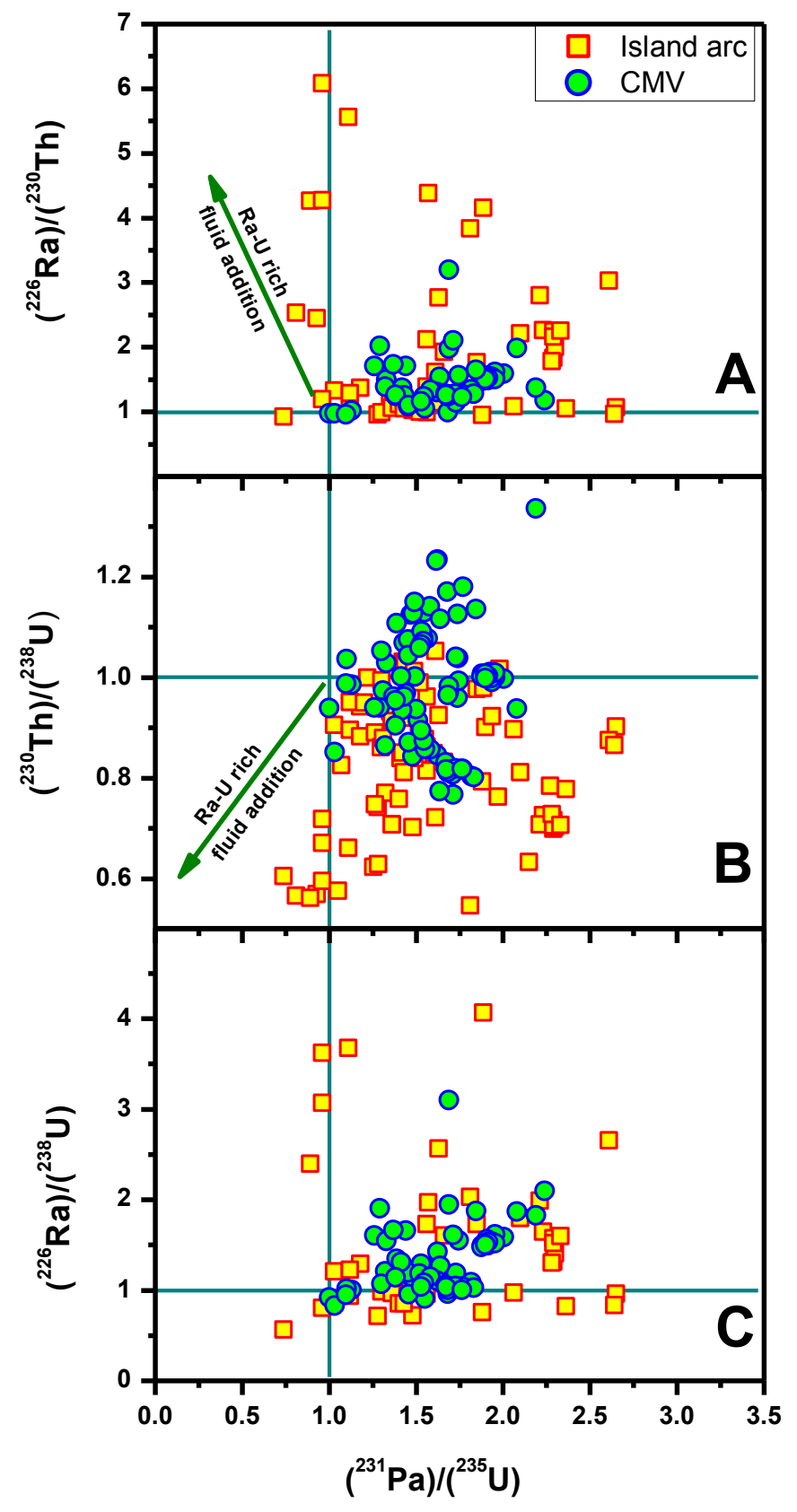

Fig. 3 

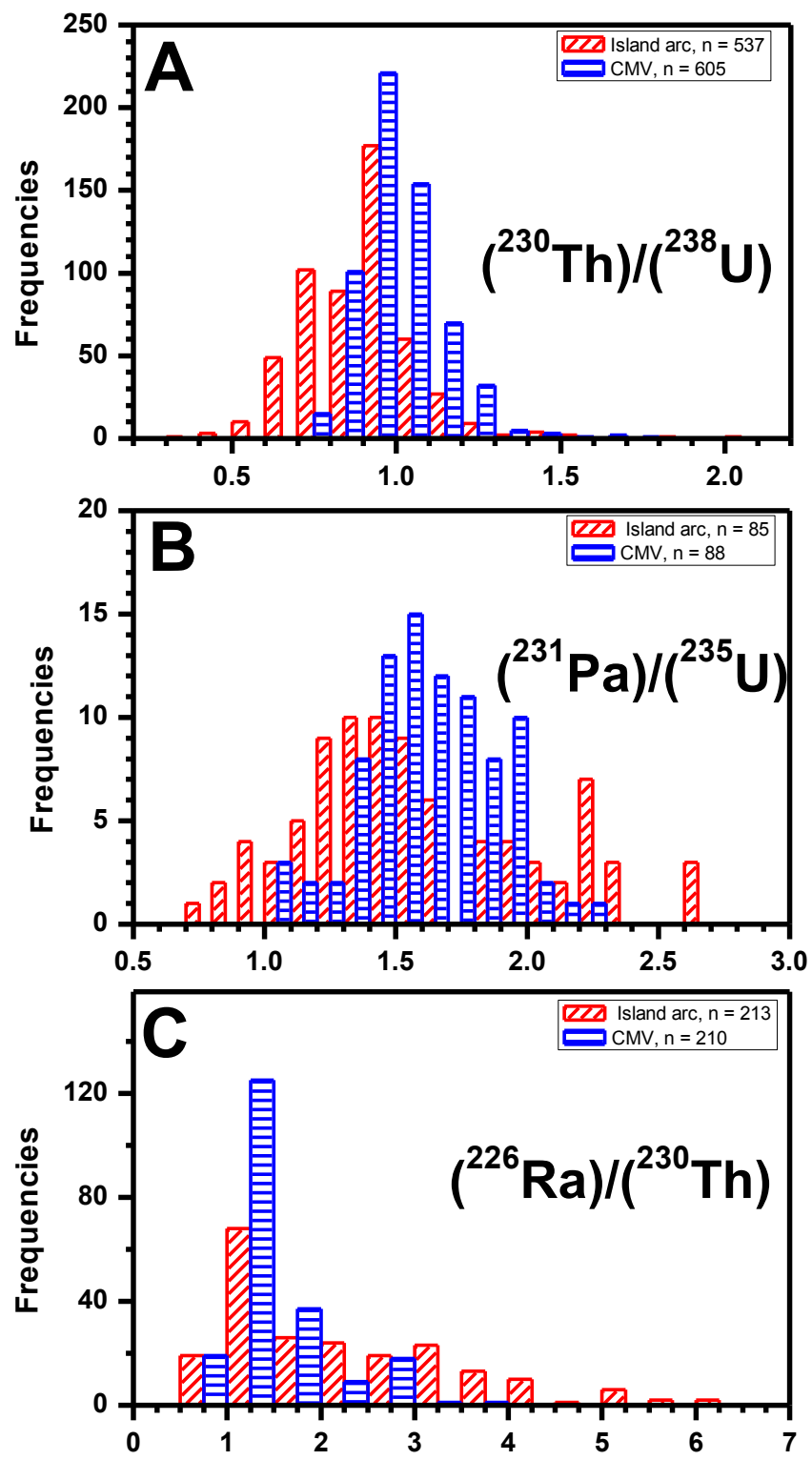

Fig. 4 

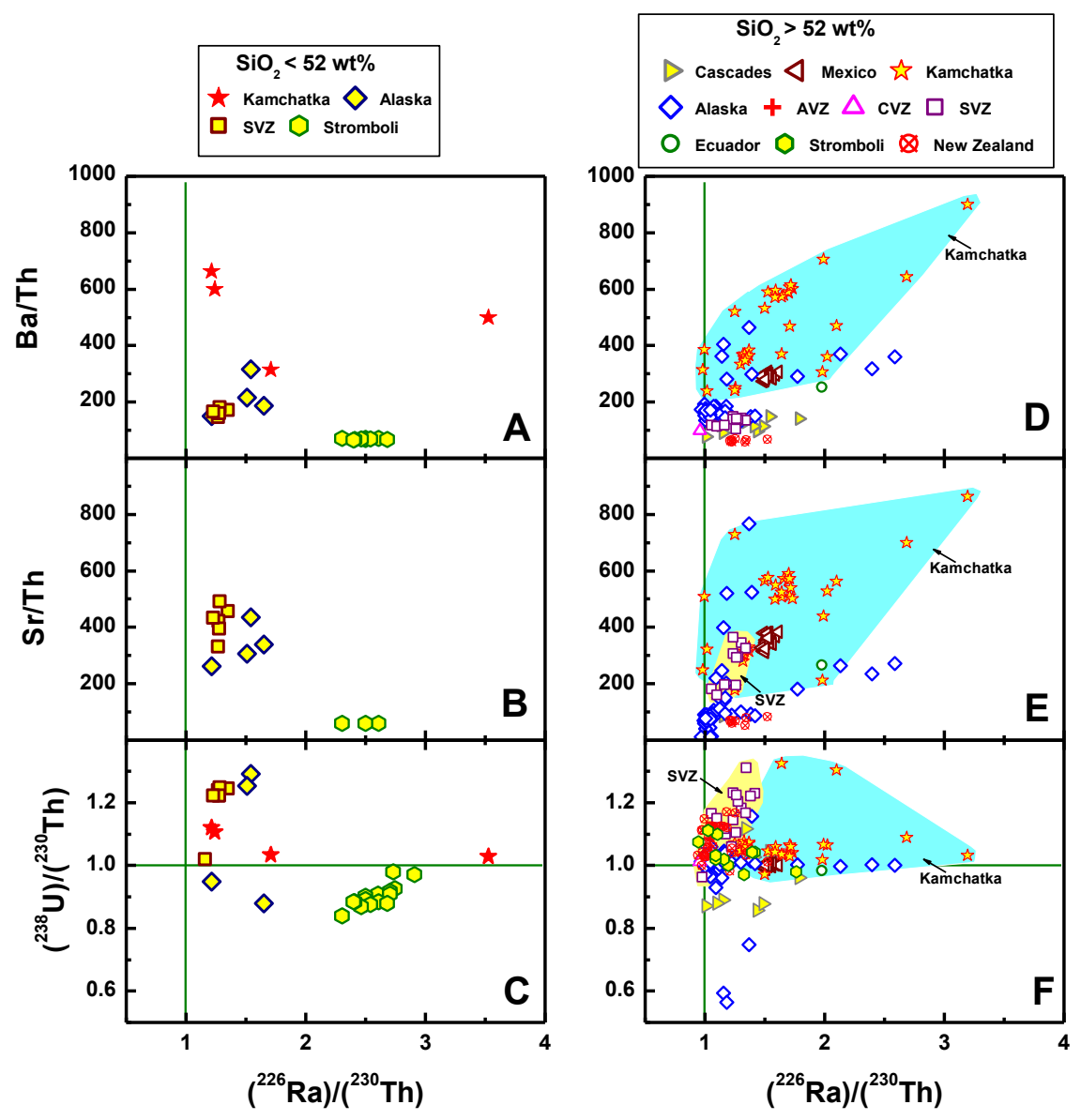

Fig. 5 

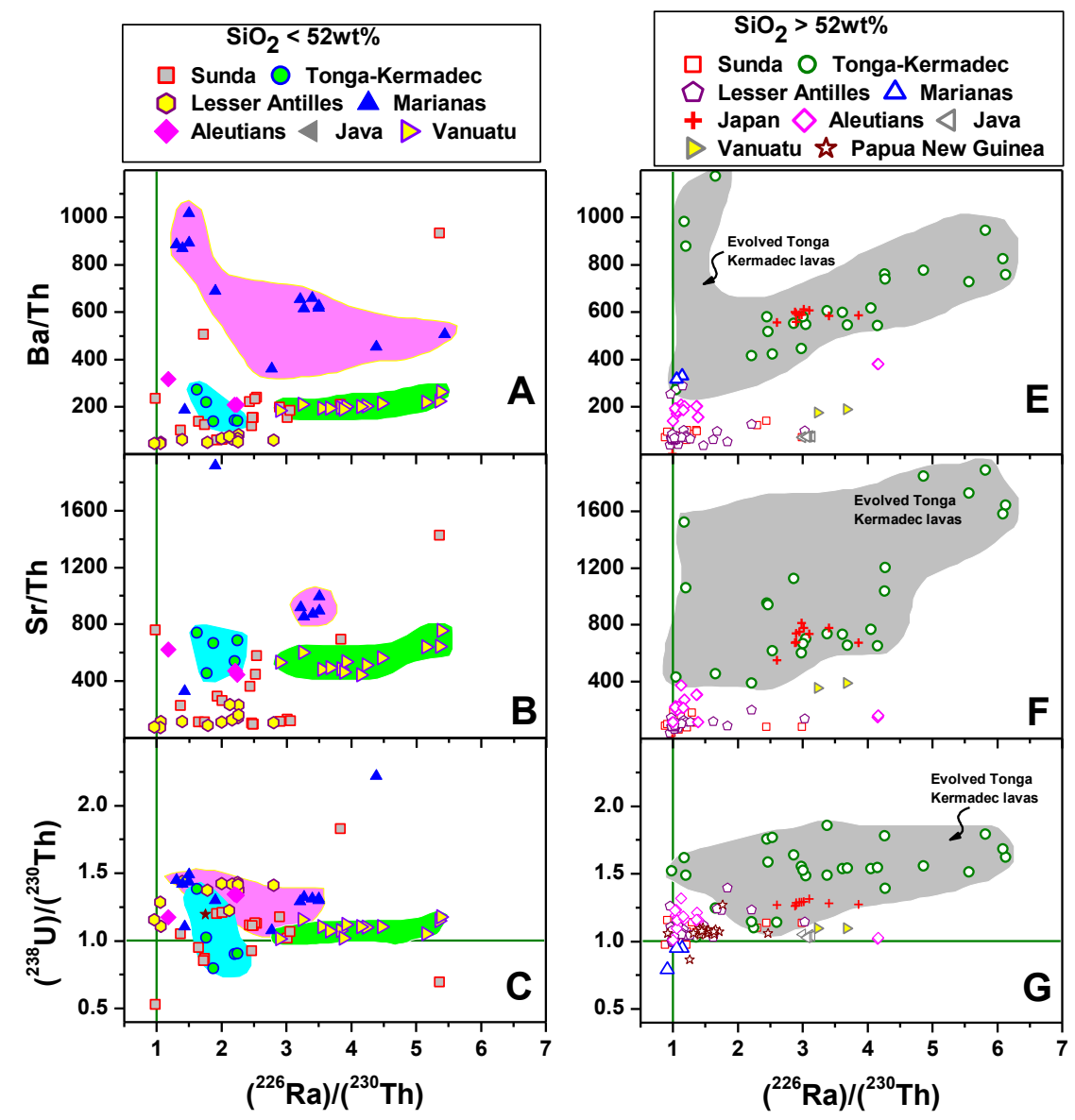

Fig. 6 


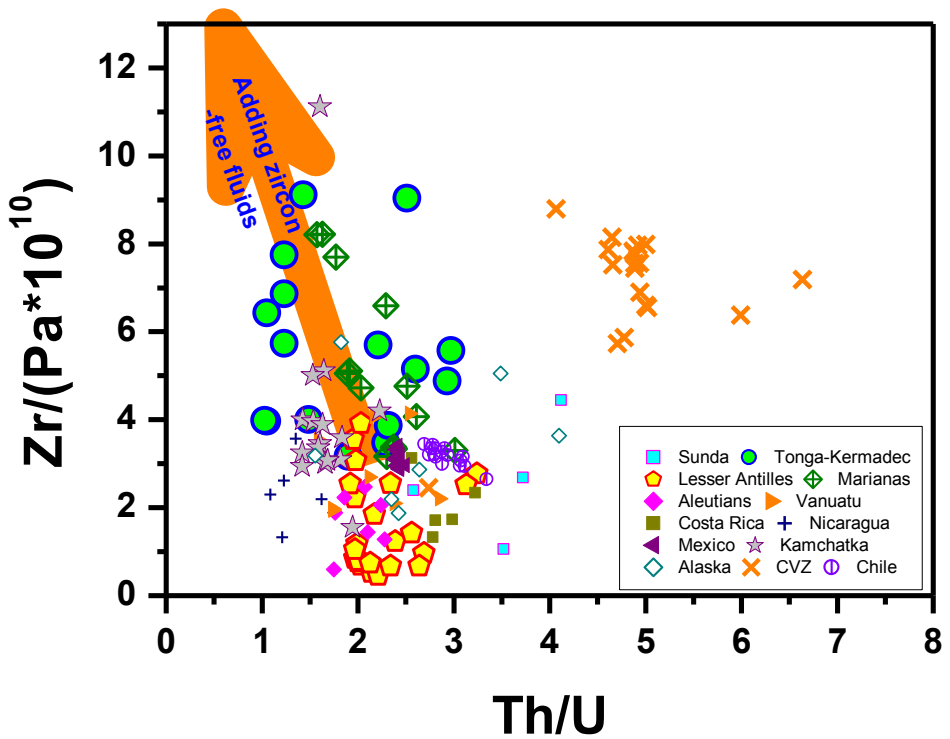

Fig. 7 

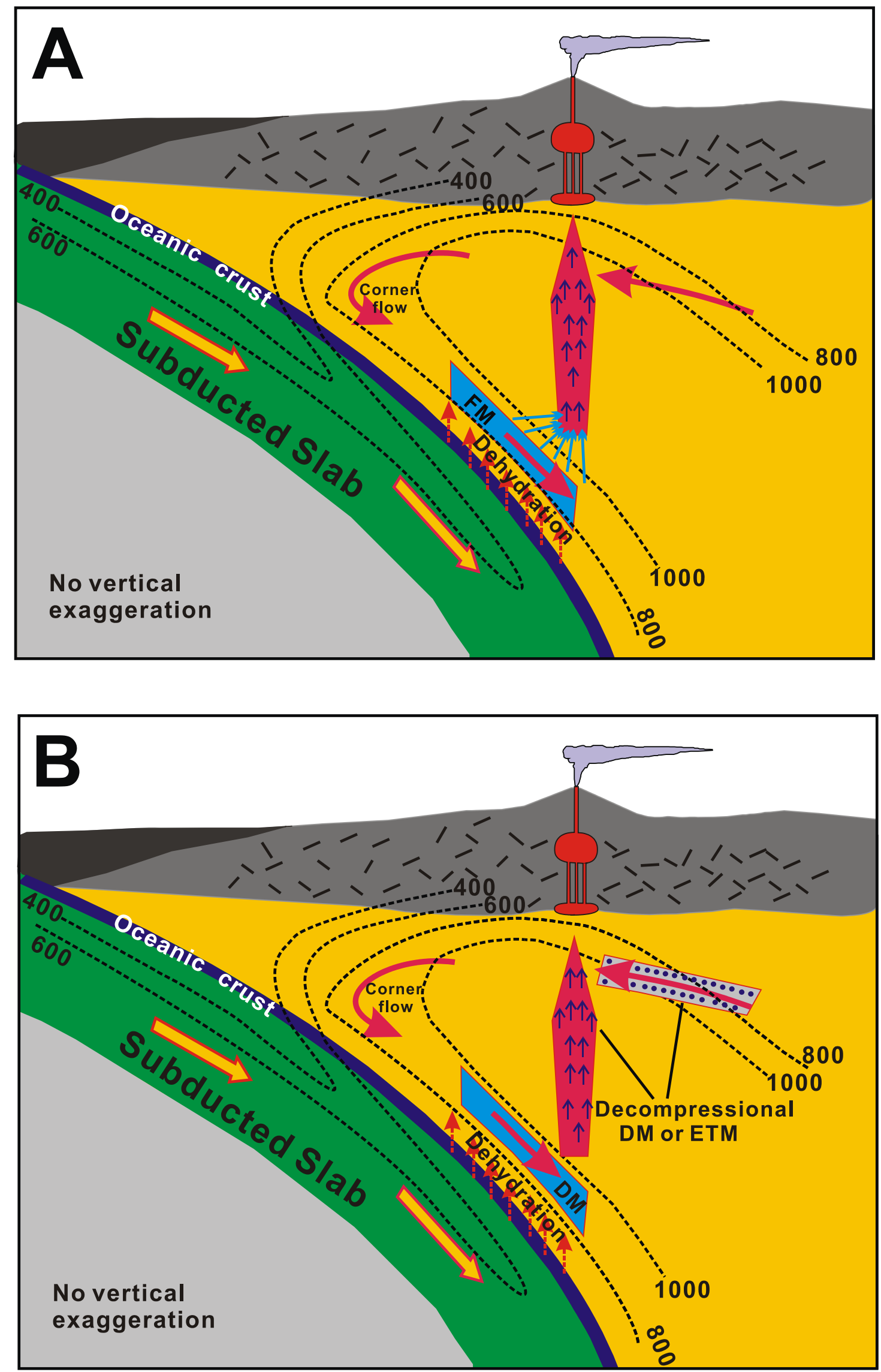

Fig. 8 


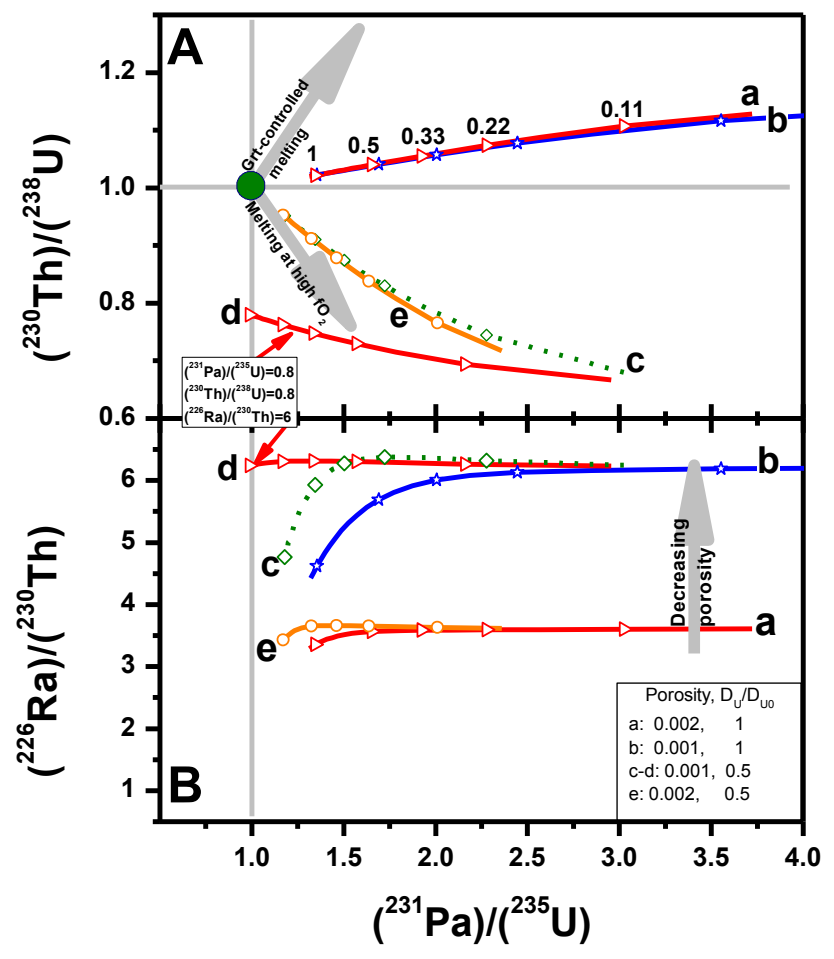

Fig. 9 


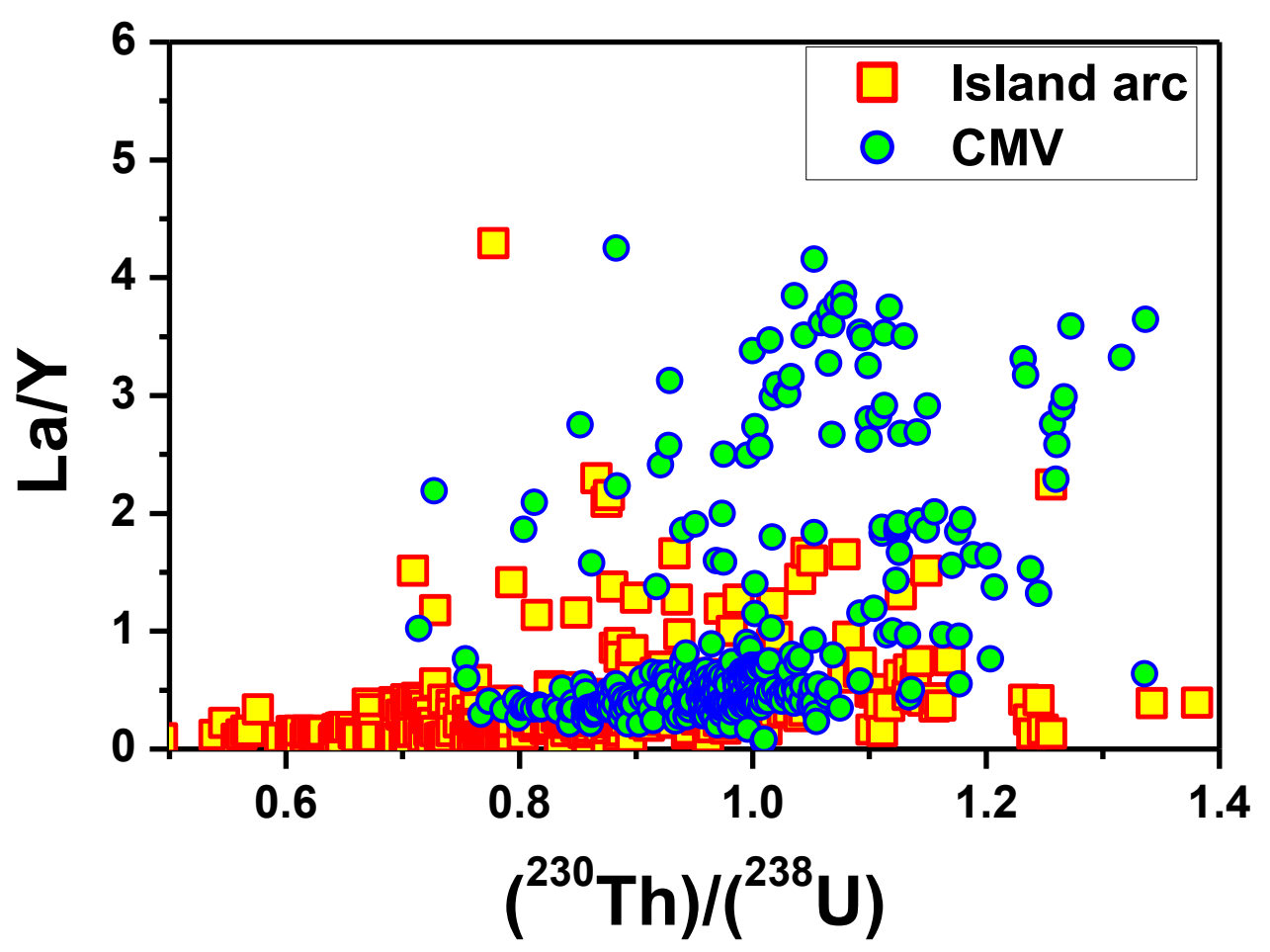

Fig. 10 

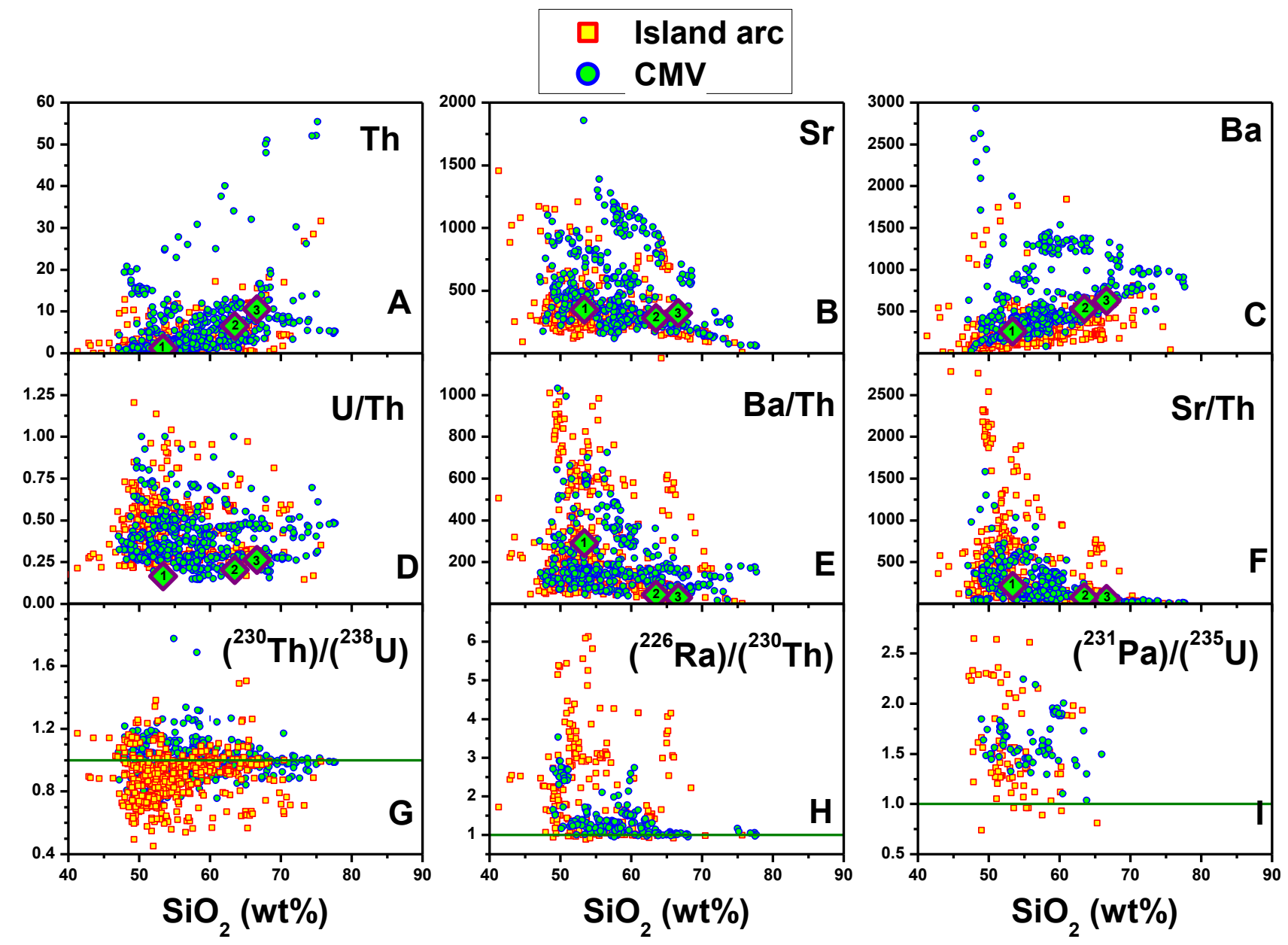

Fig. 11 


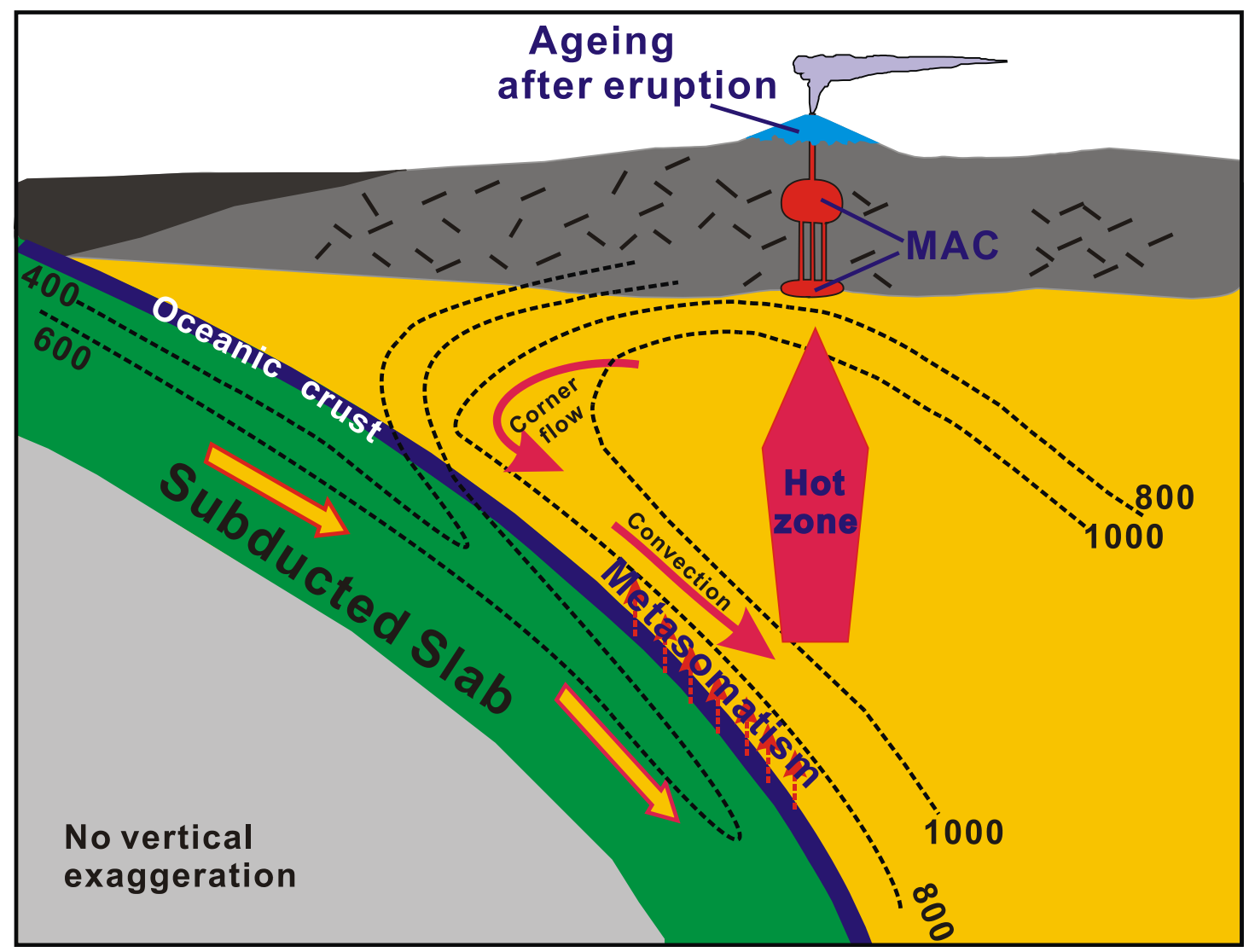

Fig. 12 